\title{
THE DEVELOPMENT OF COORDINATION CHEMISTRY IN THE SOVIET UNION
}

\author{
V. I. SPITSYN \\ Institute of Physical Chemistry of the Academy of Sciences of the \\ USSR, Moscow State Lomonossov University
}

\begin{abstract}
The report involves a review of the most important work on coordination chemistry carried out in the Soviet Union during this decade in the field of platinum metals, rare earth elements, actinides, as well as complex compounds of elements from various groups of the D. I. Mendeleev Periodic System.

The results obtained on studying heteropolyacids and complexes with different new types of ligands, including complexons, are described, new data on coordination chemistry of organo-element compounds are reported, and the results of the study of complex compounds and of the nature of their chemical bonding as obtained by various physicochemical methods are characterized. Mention is made of studies concerned with explaining the phenomenon of complex formation in terms of the D.I. Mendeleev Periodic Law. The report shows the development of coordination chemistry in the Soviet Union by its main research centres.
\end{abstract}

Soon after its publication, the coordination theory developed by Werner gained considerable support in Russia. An important contribution in this respect was made by Chugaev, discoverer of the well-known reactions for nickel with dimethylglyoxime, for osmium with thiourea, etc. Since 1904 he had been engaged in research on the chemistry of complex compounds, at first those of nickel and cobalt and later of various platinum metals. It was Chugaev who originated synthesis of a series of pentammine derivatives of platinum(IV), before unknown. He discovered the extraordinary strength of five-membered rings in complex compounds and the regularities of their formation ${ }^{1}$. In 1910 Chugaev published a monograph, On the Chemical Structure of Complex Compounds, in which he popularized and further developed Werner's ideas. The investigations of Chugaev and his co-workers laid down the foundation for a large scientific school in the Soviet Union, which carries on extensive research on the chemistry of complex compounds of platinum and other elements.

In 1926 (Cherniayev $^{2}$, while studying nitrite complexes of platinum, discovered the trans-effect, which proved to be of great importance for the further development of the chemistry of complex compounds.

Gel'man ${ }^{3}$ discovered a strong trans-effect of unsaturated organic molecules of the ethylene and acetylene type, which act as electron donors in the formation of coordination compounds. 


\section{I. SPITSYN}

By means of the trans-effect it is possible to predict the direction of reactions involving the inner sphere of coordination structures. It therefore played an outstanding part in the development of syntheses of new complex compounds.

Grinberg and collaborators made an extensive study of the acid-base and redox properties of complex compounds. It was shown that, when acted upon by alkalis, different platinum(IV) ammines behave as weak acids owing to the transition of the $\mathrm{NH}_{3}$ molecule to the amino group, $\mathrm{NH}_{2}$. This phenomenon became known as the amino reaction ${ }^{4,5}$. Amino ammines of platinum, interacting with water, enter into the opposite type of reaction and exhibit weakly basic properties. Later both Soviet ${ }^{6,7}$ and foreign authors established acidic properties of other molecules coordinated by the central atom-ethylenediamine, ethanolamine, propylenediamine, etc. Thus the reversible conversion of aquo complexes to hydroxo complexes, discovered by Pfeiffer at the beginning of this century, acquired much greater significance.

Of great interest is the intramolecular kinetic cis-effect discovered by Grinberg and Kukushkin ${ }^{8}$. Under the action of an ammonia or pyridine molecule in the cis-position, the mobility and reactivity of chlorine and bromine atoms rendered labile by opposite trans-active substituents increases.

Studies of coordination compounds, initially carried out at a few laboratories in Leningrad and Moscow, led to extensive development of the chemistry of platinum and platinum group metals; over 3000 new complex compounds of platinum metals were synthesized. The success of this work, as well as the needs of the public economy, stimulated research in the coordination chemistry of other elements, which were extended to all the groups of Mendeleev's Periodic System and involved widespread physicochemical studies. At present the problems of coordination chemistry are studied in all the Republics of the Soviet Union, in Moscow, Leningrad, Kiev, Novosibirsk, Kishinev, Minsk, Ivanovo, Kazan, Alma-Ata, Frunze, Tashkent, Tbilisi and many other cities of our country. Below a brief review is given of the most important advances in coordination chemistry made in the Soviet Union in the past five to ten years.

\section{STUDIES IN THE CHEMISTRY OF PLATINUM METALS}

The studies of Cherniayev and his collaborators were aimed mainly at further investigation of the trans-effect regularities for ligands.

The $\mathrm{x}$-ray diffraction studies of some complex compounds of platinum$\mathrm{K}\left[\mathrm{PtNH}_{3} \mathrm{Cl}_{3}\right] \cdot \mathrm{H}_{2} \mathrm{O}, \quad \mathrm{K}\left[\mathrm{PtNH}_{3} \mathrm{Br}_{3}\right] \cdot \mathrm{H}_{2} \mathrm{O}, \quad \mathrm{K}\left[\mathrm{PtC}_{2} \mathrm{H}_{4} \mathrm{Cl}_{3}\right] \cdot \mathrm{H}_{2} \mathrm{O}$ and others-showed ${ }^{9}$ that the strong trans-effect of the $\mathrm{C}_{2} \mathrm{H}_{4}$ molecule increases appreciably the interatomic distance between the central atom and the labile ligand in the complexes. For example, the distance $\mathrm{Pt}-\mathrm{X}$ along the $\mathrm{X}-\mathrm{Pt}-\mathrm{X}$ axis (where $\mathrm{X}$ is $\mathrm{Cl}, \mathrm{Br}$ ) is equal to 2.26 and $2.42 \AA$, and along the $\mathrm{X}-\mathrm{Pt}-\mathrm{C}_{2} \mathrm{H}_{4}$ axis -2.40 and $2.50 \AA$, respectively.

In recent years new data on the trans-activity of various atoms and molecules have been obtained. Cherniayev, Nazarova and Mironova ${ }^{10}$ studied the nitrous complexes of platinum(IV) formed when platinum(II) compounds are treated with concentrated nitric acid. The strong trans-activity of a nitrosogroup (NO) made it possible to introduce in the opposite position 
various ligands which under ordinary conditions do not enter into the coordination sphere of platinum(Iv): $\mathrm{C}_{2} \mathrm{O}_{4}^{2-}, \mathrm{HC}_{2} \mathrm{O}_{4}^{-}, \mathrm{ClO}_{4}^{-}, \mathrm{IO}_{3}^{-}$.

Further advances were made in the synthesis and investigation of the properties of new geometric isomeric compounds of bivalent and tetravalent platinum. Gel'man and her collaborators ${ }^{11,12}$ synthesized seven geometric isomers of platinum(Iv) compounds of composition [ $\mathrm{PtPyNH} \mathrm{ClBrINO}_{2}$ ] out of 15 theoretically possible. Also about twenty platinum(II) compounds of the type [Ptabcd], unknown before, were isolated and among them several triads of geometric isomers. The compounds of composition $\left[\mathrm{PtNH}_{3} \mathrm{PyBrNO}_{2}\right], \quad\left[\mathrm{PtC}_{8} \mathrm{H}_{8} \mathrm{PyClBr}\right], \quad\left[\mathrm{PtCH}_{3} \mathrm{NH}_{2} \mathrm{PyNH}_{3} \mathrm{NO}_{2}\right] \mathrm{X}$ and $\left[\mathrm{PtC}_{2} \mathrm{H}_{5} \mathrm{NH}_{2} \mathrm{PyNH} \mathrm{NH}_{3} \mathrm{Br}\right.$, where $\mathrm{X}$ is $\mathrm{Cl}, \mathrm{Br}$ or $\left[\mathrm{PtCl}_{4}\right]^{2-}$, can be taken as examples of these.

Simultaneously with the work of Adamson ${ }^{13}$ on the photochemistry and photoracemization of complex compounds of cobalt and chromium, studies were made by Soviet authors ${ }^{14}$ of the photoisomerization of cis-diammines of platinum(IV) - the transition under the action of light of an asymmetrical structure to a symmetrical one. It was established that photoisomerization is a redox process at intermediate stages of which the valency of the central atom and the composition of intraspherical ligands undergo a change:

$$
\mathrm{H}_{3} \mathrm{~N}{\underset{\mathrm{X}}{\mathrm{Pt}} \mathrm{X}_{\mathrm{X}}^{\mathrm{N}}}_{\mathrm{NO}_{2}}^{\mathrm{NO}_{2}}
$$

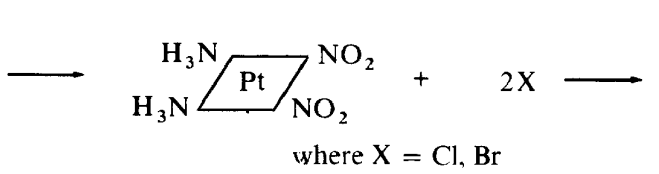

$$
\mathrm{H}_{3} \mathrm{~N} \rightleftharpoons \mathrm{Pt} \mathrm{C}_{\mathrm{X}}^{\mathrm{NO}_{2}}+\mathrm{NO}_{2}+\mathrm{X}
$$

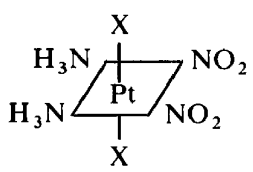

Further investigation of amino reactions led Grinberg and his collaborators $^{15}$ to prepare complexes with intraspherical silver amide from solutions containing $\mathrm{Ag}^{+}$ions and amino compounds of platinum(Iv):

$$
\begin{aligned}
& {\left[\mathrm{Pt}\left(\mathrm{NH}_{3}\right)_{6}\right]^{4+}+\mathrm{OH}^{-} \rightleftharpoons\left[\mathrm{Pt}\left(\mathrm{NH}_{3}\right)_{5} \mathrm{NH}_{2}\right]^{3+}+\mathrm{H}_{2} \mathrm{O}} \\
& {\left[\mathrm{Pt}\left(\mathrm{NH}_{3}\right)_{5} \mathrm{NH}_{2}\right]^{3+}+\mathrm{Ag}^{+} \rightleftharpoons\left[\mathrm{Pt}\left(\mathrm{NH}_{3}\right)_{5} \mathrm{NH}_{2} \mathrm{Ag}\right]^{4+}}
\end{aligned}
$$

These can be considered as silver salts of platinum ammines. Now it is an established fact that similar compounds are formed also for thallium(I), but they are less stable than those of silver ${ }^{16}$.

Another interesting result was obtained by Grinberg and Kukushkin ${ }^{17}$, who showed that interaction of an alkali with ethylenediamine tetrammine of platinum(IV), $\left[\mathrm{PtEn}_{2} \mathrm{Cl}_{2}\right] \mathrm{Cl}_{2}$, causes free radicals to be formed, the presence of which was proved by the polymerization of acrylonitrile. The mechanism of this process can be represented by the following steps: 


\section{I. SPITSYN}<smiles>CC(CN)[PH+](N)CC[PH2+]</smiles>

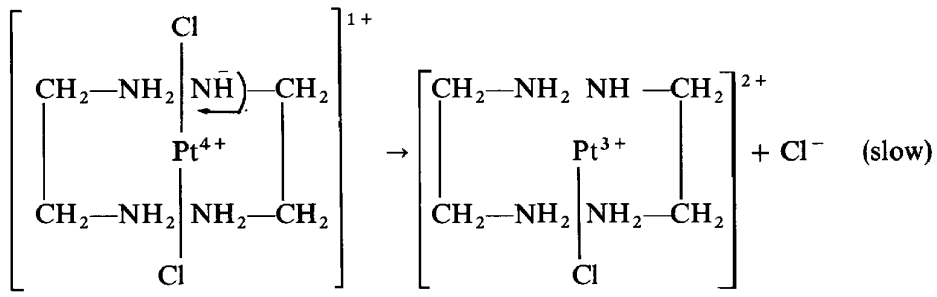

A repetition of this process, which may involve a disproportionation reaction of a compound of platinum(III), should lead to a compound of platinum(II) containing the radical $\mathrm{NHCH}_{2} \mathrm{CH}_{2} \mathrm{NH}_{2}$. It may be that these radicals interact with water according to the following scheme:

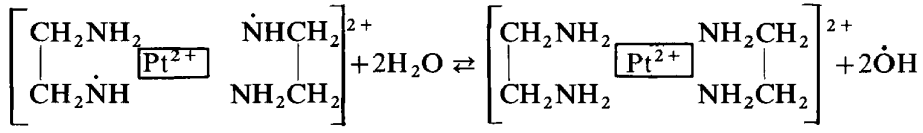

Thus we see that it is possible in principle to use complex compounds as a source of free radicals, e.g. for initiation of polymerization reactions.

Synthesis of new compounds and study of their properties were carried out for all platinum metals. Some of the most interesting results are reported below.

Unexpectedly, rhodium formates and acetates, $\mathrm{Rh}\left(\mathrm{HCO}_{2}\right)_{2} \cdot \frac{1}{2} \mathrm{H}_{2} \mathrm{O}$ and $\mathrm{Rh}\left(\mathrm{CH}_{3} \mathrm{CO}_{2}\right)_{2} \cdot \mathrm{H}_{2} \mathrm{O}$, proved to be stable compounds ${ }^{18,19}$. An $\mathrm{x}$-ray diffraction study led to the conclusion ${ }^{20}$ that they are dimers with cyclic carboxylate groups and a direct bond between the two rhodium atoms. A scheme of the structure of rhodium(II) acetate is given ${ }^{21}$ on page 197. Other

- ligands can be readily substituted for water molecules on the coordinate $\mathrm{H}_{2} \mathrm{O}-\mathrm{Rh}-\mathrm{Rh}-\mathrm{H}_{2} \mathrm{O}$. Thus it can be concluded that metal atoms with their electrons exhibit here an appreciable trans-effect.

Important results were obtained in the studies of $\pi$-complexes of palladium by Syrkin, Moiseev and their collaborators. It was established ${ }^{22}$ that in aqueous solutions of palladium(II) salts ethylene can be catalytically converted to acetaldehyde, in acetate solutions to vinylacetate and in alcohol solutions to dialkylacetal. The catalytic process consists of alternating steps 


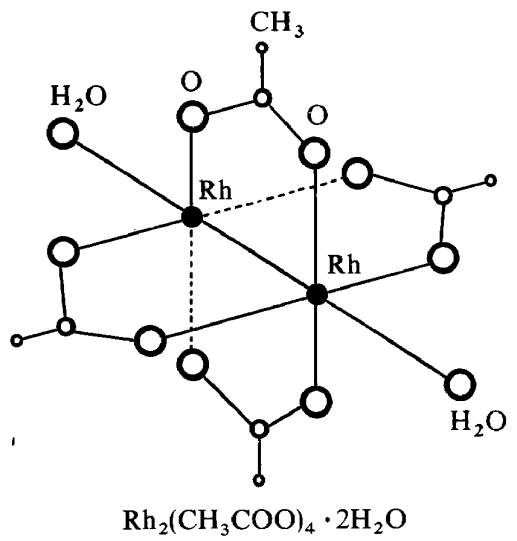

of olefin oxidation by the palladium salt and subsequent regeneration of the palladium(II) salt by interaction of the compounds of zero-valent palladium with the oxidant.

Investigation of the mechanism of these reactions showed ${ }^{23}$ that they occur via the reversible steps of formation of $\pi$-complexes and their irreversible redox decomposition yielding a reduced form of palladium and an oxidation product of the olefin ligand. Decomposition includes the conversion of the $\pi$-complex into a sigmabonded organic palladium compound :

$$
\begin{aligned}
& \mathrm{C}_{2} \mathrm{H}_{4}+\mathrm{PdCl}_{4}^{2-}=\mathrm{C}_{2} \mathrm{H}_{4} \mathrm{PdCl}_{3}^{-}+\mathrm{Cl}^{-} \text {; } \\
& \mathrm{C}_{2} \mathrm{H}_{4} \mathrm{PdCl}_{3}^{-}+\mathrm{H}_{2} \mathrm{O}=\mathrm{C}_{2} \mathrm{H}_{4} \mathrm{PdCl}_{2} \mathrm{OH}_{2}+\mathrm{Cl}^{-} \\
& \mathrm{C}_{2} \mathrm{H}_{4} \mathrm{PdCl}_{2} \mathrm{OH}_{2}+\mathrm{H}_{2} \mathrm{O}=\mathrm{C}_{2} \mathrm{H}_{4} \mathrm{PdCl}_{2} \mathrm{OH}+\mathrm{H}_{3} \mathrm{O}^{+} \\
& \pi-\left[\mathrm{Cl}_{2} \mathrm{PdC}_{2} \mathrm{H}_{4} \mathrm{OH}\right]^{-} \rightarrow \sigma-\left[\mathrm{Cl}_{2} \mathrm{PdCH}_{2} \mathrm{CH}_{2} \mathrm{OH}\right]^{-}
\end{aligned}
$$

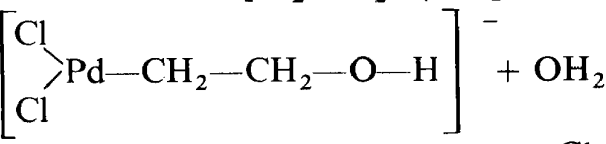

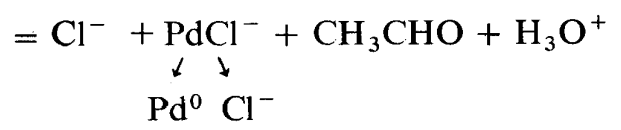

\section{STUDIES ON HETEROPOLYCOMPOUNDS (HPC)}

A. L. Davydov ${ }^{24}$ was the first to synthesize polynuclear HPC. In 1947 he obtained a phosphoniobomolybdic complex in a solution containing phosphates, molybdates and niobates.

At present many new complexes of this kind are known, prepared by Babko and collaborators ${ }^{25}$. The composition was determined in solution spectrophotochemically by the isomolar series method. It was shown that a phosphotitanomolybdic complex is characterized by the ratio, $\mathrm{P}: \mathrm{Ti}: \mathrm{Mo}=$ $1: 1: 12$, and the caesium salt isolated in solid state has the composition $\mathrm{Cs}_{2} \mathrm{O} \cdot \frac{1}{2} \mathrm{P}_{2} \mathrm{O}_{5} \cdot \mathrm{TiO}_{2} \cdot 12 \mathrm{MoO}_{3} \cdot n \mathrm{H}_{2} \mathrm{O}$. For a phosphozirconomolybdic complex the ratio, $\mathrm{P}: \mathrm{Zr}: \mathrm{Mo}$, was also found to be $1: 1: 12$. 


\section{I. SPITSYN}

It was established on the basis of systematic studies by Babko and Shkaravsky ${ }^{26,27}$ that niobium, titanium and zirconium enter into the composition of the complex as the second central atom.

Cases are known where HPC with several central atoms of similar metallic nature are formed, which are split off, however, on the cationite. In our laboratory Torchenkova et $_{\mathrm{al}}{ }^{28}{ }^{2}$, when studying the interaction of a ceriummolybdic compound with ions of trivalent rare earth elements, found that these are incorporated into the heteropolyanion:

$$
\begin{aligned}
\mathrm{H}_{8}\left[\mathrm{Ce}^{\mathrm{IV}} \mathrm{Mo}_{12} \mathrm{O}_{42} \cdot n \mathrm{H}_{2} \mathrm{O}\right]+2 \mathrm{MCl}_{3} & \\
\rightarrow & \mathrm{H}_{4}\left[\mathrm{Ce}^{\mathrm{IV}} \mathrm{Mo}_{12} \mathrm{O}_{42}(\mathrm{OH})_{2} \mathrm{M}_{2}(n-2) \mathrm{H}_{2} \mathrm{O}\right]+6 \mathrm{HCl}
\end{aligned}
$$

In a polynuclear complex formed bonding seems to be as olbridges. It has been established ${ }^{29}$ that interaction of potassium niobate and ammonium ceriummolybdate leads to the formation of a polynuclear complex :

$$
\mathrm{H}_{2}\left[\mathrm{CeMo}_{12} \mathrm{O}_{42}\right]^{6-}+2 \mathrm{NbO}_{3}^{-} \rightarrow\left[\mathrm{CeMo}_{12} \mathrm{O}_{46} \mathrm{Nb}_{2}\right]^{6-}+2 \mathrm{OH}^{-}
$$

which is stable over a wide range of $\mathrm{pH}$ from 1.9 to 11.9. Upon contact with cationite in the $\mathrm{H}^{+}$form, one of the niobium atoms is split off, which involves a rearrangement of the anion coordination sphere. As a result, both cerium and niobium atoms become central with respect to the twelve molybdenum atoms. The charge loss, caused by the splitting off of one of the pentavalent niobium atoms, is compensated for by the addition of five hydroxonium ions, which leads to the formation of a highly basic polynuclear heteropolyanion:

$$
\mathrm{H}_{6}\left[\mathrm{CeMo}_{12} \mathrm{O}_{46} \mathrm{Nb}_{2}\right] \frac{\mathrm{H}^{+}}{\mathrm{H}_{2} \mathrm{O}} 0,5 \mathrm{Nb}_{2} \mathrm{O}_{5 \text { aq }}+\mathrm{H}_{11}\left[\mathrm{CeNbMo}_{12} \mathrm{O}_{46}\right]
$$

Systematic studies of mixed HPC, i.e. compounds containing in their anion several different metal oxides as ligands surrounding the central atom, were carried out by Kokorin and collaborators ${ }^{30}$. They developed synthetic methods and obtained in the solid state over twenty mixed acids with phosphorus, silicon, arsenic, germanium and boron as the central atom, including as ligands oxides of molybdenum and tungsten, molybdenum and vanadium, tungsten and vanadium, and also three oxides simultaneouslymolybdenum, tungsten and vanadium, e.g.:

$$
\begin{aligned}
& \mathrm{P}_{2} \mathrm{O}_{5} \cdot 20 \mathrm{MoO}_{3} \cdot \mathrm{V}_{2} \mathrm{O}_{5} \cdot 59 \mathrm{H}_{2} \mathrm{O} \\
& \mathrm{P}_{2} \mathrm{O}_{5} \cdot 20 \mathrm{MoO}_{3} \cdot 4 \mathrm{WO}_{3} \cdot 59 \mathrm{H}_{2} \mathrm{O} \\
& \mathrm{P}_{2} \mathrm{O}_{5} \cdot 16 \mathrm{MoO}_{3} \cdot 4 \mathrm{WO}_{3} \cdot 2 \mathrm{~V}_{2} \mathrm{O}_{5} \cdot 67 \mathrm{H}_{2} \mathrm{O}
\end{aligned}
$$

As with the investigation of polynuclear and mixed heteropolycompounds, great attention was paid to the study of HPC with a tetravalent central metal atom. On the basis of a detailed study of the optimum conditions of formation of heteropolyanions, Shakhova and collaborators ${ }^{31}$ developed quite a number of new methods for the analytical determination of germanium, silicon, cerium and tellurium. Investigation of the behaviour in solutions of yellow unreduced and blue reduced forms of heteropolyacids ${ }^{32}$ showed that formation of the blue form does not involve decomposition of the heteropolyanion, its structure is retained, but molybdenum( $\mathrm{V})$ in the anion is partly reduced to molybdenum(v). 
It was shown in our laboratory ${ }^{33}$ that HPC of tetravalent cerium and thorium and recently synthesized tetravalent uranium derivatives form a special group in the chemistry of HPC. They are characterized by stability of the anions in alkaline and strongly acid media, high basicity of acids and low solubility of the free heteropolyacids in a strongly acid medium. On this basis a method was developed for the isolation of heteropolyacids of cerium(IV), thorium and uranium(IV) in the crystalline state of general formula $\mathrm{H}_{8}\left[\mathrm{MeMo}_{12} \mathrm{O}_{42}\right] \cdot 18 \mathrm{H}_{2} \mathrm{O}$.

Of particular importance also are the studies of the form and state of bound water in HPC, carried out by means of the p.m.r. method ${ }^{34}$. On this basis, it is possible to assess unambiguously the basicity of heteropolyacids and the arrangement of hydrogen ions in the structure of the anions for crystal samples, without complications due to dissolution processes.

The first compound to be investigated was phosphomolybdic acid ${ }^{35}$, then phosphotungstic and silicotungstic ${ }^{36}$; also borotungstic acids ${ }^{37}$ and some of their salts (Figure 1).

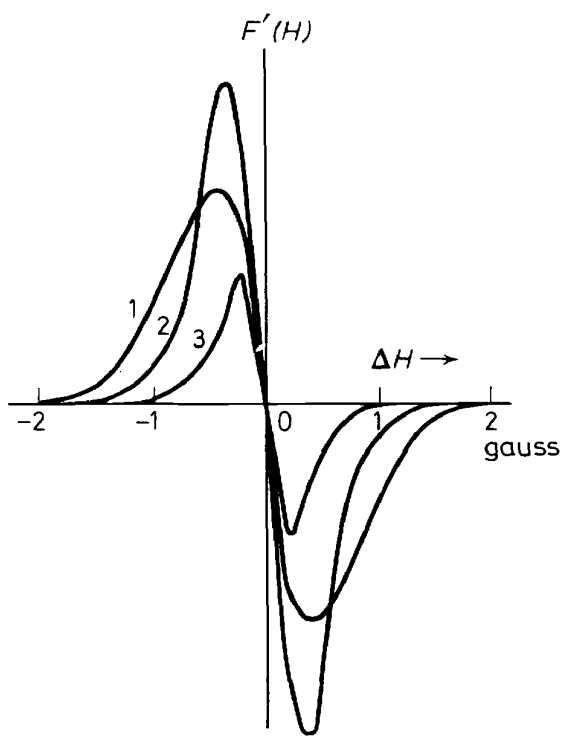

Figure 1. Experimental derivatives of the proton absorption lines at $80^{\circ} \mathrm{K}$ in compounds $1, \mathrm{H}_{4} \mathrm{SiW}_{12} \mathrm{O}_{40} ; 2, \mathrm{H}_{3} \mathrm{PW}_{12} \mathrm{O}_{40} ; 3, \mathrm{Na}_{2} \mathrm{HPW}_{12} \mathrm{O}_{40}$. The areas limited by the curves 1,2 and 3 are proportional to the number of $\mathrm{H}$ atoms in the compounds studied, that is, they are in the ratio $4: 3: 1$ respectively.

The structure of HPC listed above shows systems of isolated protons. No phenomena of non-equivalence of protons, which are responsible for the acidic properties of HPC, are observed. The basicity of the heteropolyacids studied corresponds to the basicity of the non-metallic acid on which they are based. Examination of p.m.r. data made it possible to refine the concepts of the structure of these compounds. In highly hydrated HPC hydrogen ions exist as hydroxonium ions, $\mathrm{H}_{3} \mathrm{O}^{+}$. Low hydrated $\mathrm{HPC}$ are characterized by 
formation of the groups $\mathrm{H}^{+}+\mathrm{H}_{2} \mathrm{O}$ in which interprotonic distances are somewhat less than those known for the $\mathrm{H}_{3} \mathrm{O}^{+}$ion (Figure 2).

The basicity of heteropolyacids depends on the value of the coordination number of the central atom of the anions. At present it is a well-established

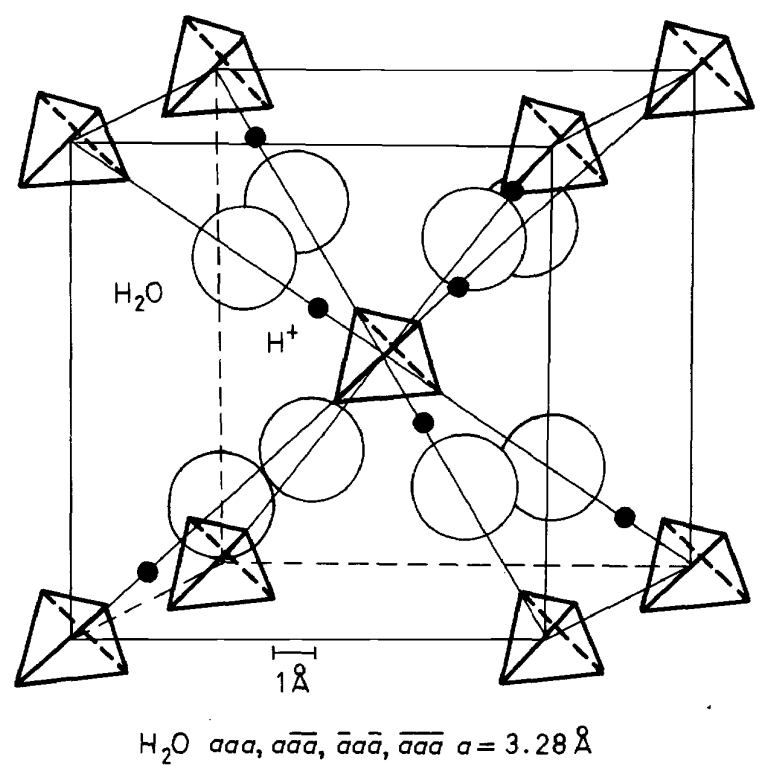

Figure 2. Arrangement of $\mathrm{H}^{+}$ions and eight water molecules in unit cell of silicotungstic acid.

fact that in heteropolyanions, phosphorus, silicon and boron exhibit the coordination number four. Therefore, the basicity of "classical' heteropolyacids - phosphomolybdic, silicotungstic, etc. does not exceed the basicity of the non-metallic acids used in their formation. Thus, the hypothesis of MiolatiRosenheim that in HPC phosphorus, silicon and boron are characterized by the coordination number six must be rejected. For this reason, the so-called 'high substitution salts' of heteropolyacids described by a number of authors should be considered as mixtures formed during the decomposition of HPC when the $\mathrm{pH}$ of the solution is increased. In recent years this concept has been supported by many studies, both by Soviet ${ }^{38,39}$ and foreign authors.

However, a high basicity of heteropolyacids with central atoms having coordination number six or higher is observed in practice, as exemplified by ceriummolybdic, thoriummolybdic and some other acids mentioned above.

\section{COMPLEX COMPOUNDS OF RARE EARTH ELEMENTS}

In our laboratory, Martynenko and collaborators have made a systematic study of the complex compounds of rare earths with many organic ligands: oxycarboxylic acids ${ }^{40,41}$, beta-diketones ${ }^{42}$, derivatives of the selenophene series ${ }^{43}$ and various complexons ${ }^{44-48}$. The object of these studies was to establish the dependence of the structure of complexes on the ionic radius 
COORDINATION CHEMISTRY IN THE USSR

Table 1. Variation in the hydrate composition of complexonates of lanthanides $(\mathrm{Ln})$

\begin{tabular}{|c|c|c|c|c|}
\hline Complexon & \multicolumn{4}{|c|}{ Type of compound and number of water molecules in the hydrates } \\
\hline $\begin{array}{l}\text { Iminodiacetic } \\
\text { acid, } \\
\mathrm{H}_{2} \mathrm{Z}\end{array}$ & $\begin{array}{l}{[\mathrm{LnZ}] \mathrm{Cl}} \\
\mathrm{Me}^{\mathrm{I}}\left[\mathrm{LnZ}_{2}\right]\end{array}$ & $\begin{array}{c}\mathrm{La}-\mathrm{Eu} \\
2\end{array}$ & $\begin{array}{l}\mathrm{Gd} \\
2,3 \\
\mathrm{La}-\mathrm{Lu} \\
\quad 3\end{array}$ & $\begin{array}{c}\mathrm{Tb}-\mathrm{Yb} \\
3\end{array}$ \\
\hline $\begin{array}{l}\text { Nitrilotriacetic } \\
\text { acid, } \\
\mathbf{H}_{3} \mathbf{X}\end{array}$ & $\begin{array}{l}\operatorname{LnX} \\
\operatorname{Me}_{3}^{I}\left[\operatorname{LnX} X_{2}\right]\end{array}$ & $\begin{array}{l}\mathrm{La}-\mathrm{Nd} \\
5,3 \\
\mathrm{La} \\
4\end{array}$ & $\begin{array}{l}\text { Sm-Gd } \\
5,4,3 \\
\text { Pr-Tu } \\
\quad 6\end{array}$ & $\begin{array}{l}\mathrm{Tb}-\mathrm{Yb} \\
4 \\
\mathrm{Yb} \\
3\end{array}$ \\
\hline $\begin{array}{l}\text { Ethylenediaminetetra- } \\
\text { acetic acid, } \\
\mathrm{H}_{4} \mathrm{~A}\end{array}$ & $\begin{array}{l}\mathrm{H}[\operatorname{Ln} \mathrm{A}] \\
\mathrm{Me}^{\mathrm{I}}[\operatorname{Ln} \mathrm{A}]\end{array}$ & $\begin{array}{l}\mathrm{La} \\
1,7\end{array}$ & $\begin{array}{cc}\text { Pr-Sm } & \text { Gd-Tb } \\
1,6 \quad 3,4(7) \\
\text { La-Lu } \\
8\end{array}$ & $\begin{array}{c}\mathrm{Dy}-\mathrm{Lu} \\
3\end{array}$ \\
\hline
\end{tabular}

value of rare earths and to determine the effect of the resulting structure on the nature of the variation of the stability constants of the complex compounds in the rare earth series, with a view to developing the structure of complexes with the greatest difference in stability constants for individual rare earths.

The change in the bound water content in the complexonate crystals in the rare earth series is usually the result of a change in the structure of the complexes (Table 1).

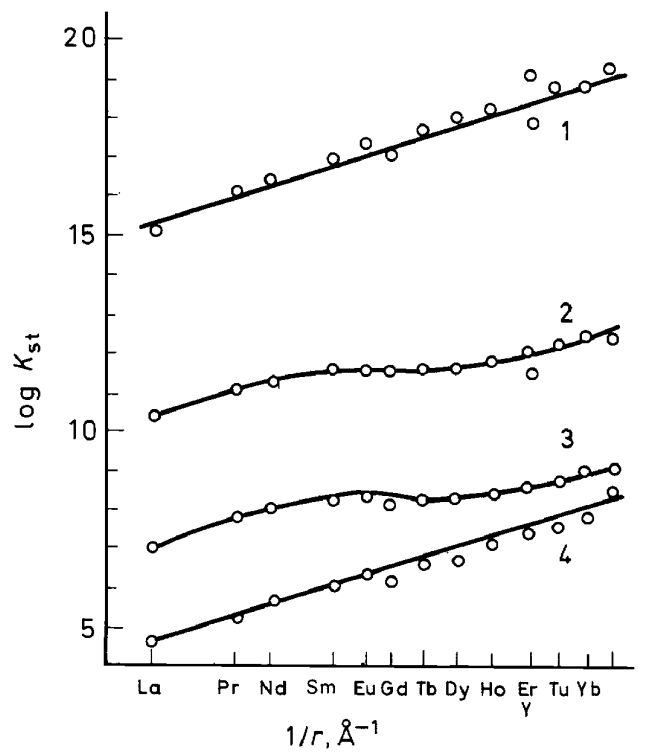

Figure 3. Dependence of logarithm of stability constant $\left(K_{\mathrm{st}}\right)$ on $1 / r(r$ is the ionic radius of the rare earth element). $1, \log K_{1}$ of ethylenediaminetetraacetates. K[LnA]. $2, \log K_{1}$ of mononitrilotriacetates, $\left[\mathrm{LnX}\right.$ ]. 3, $\log K_{1}$ of monoethylenediaminediacetates [LnE]Cl. 4, $\log K_{2}$ of diethylenediaminediacetates, $\mathrm{K}\left[\mathrm{LnE}_{2}\right]$. 


\section{I. SPITSYN}

As can be seen from a comparison (Figure 3) of the stability constant values (taken from ref. 49) and the data given in Table 1 , in many cases the changes in hydrate composition of solid complexonates run parallel to those of the values of $\log K_{\mathrm{st}}$ in the rare earth series. Higher complexonates formed by low-dentate ligands and complexonates-derivatives of high dentate ligands - correspond to a less strained structure (constant hydrate composition) and a nearly linear change of $\log K_{\mathrm{st}}$ in the rare earth series. On the contrary, unsaturated complexonates of low-dentate ligands having a strained structure, correspond to a curvilinear dependence of $\log K_{\mathrm{st}}$ on $1 / r$.

Of several crystal hydrates, the complex undergoing the least intermolecular ( $\mathrm{H}$-bonds) and interionic distortion in the crystal lattice shows the greatest structural similarity to the complexonate dissolved in water. These are neutral complexonates, the anion is formed with a weakly polarizing outer sphere cation and the cation complexonates with a weakly polarized anion.

The change of the structure of dissolved complexonates in the rare earth series manifests itself in their behaviour towards ionites as well. Martynenko and collaborators ${ }^{46,50}$ were the first to show that the anionic, neutral and cationic forms of complexonates can be sorbed by cationite not by ion exchange. The rare earth compounds, sorbed by the non-ion exchange forces, can be removed from the resin simply by washing with water. The nonion exchange sorption and hence the structure of the complexonates of given composition (e.g. $[\mathrm{LnA}]^{-}$and $[\mathrm{LnX}]$ ), undergo changes in the rare earth series, parallel to those of $\log K_{\mathrm{st}}$.

It is interesting to note that the complexes sorbed by cationite play an important kinetic role in the ion-exchange separation of rare earth mixtures. The compounds capable of non-ion-exchange sorption are rare earth ion

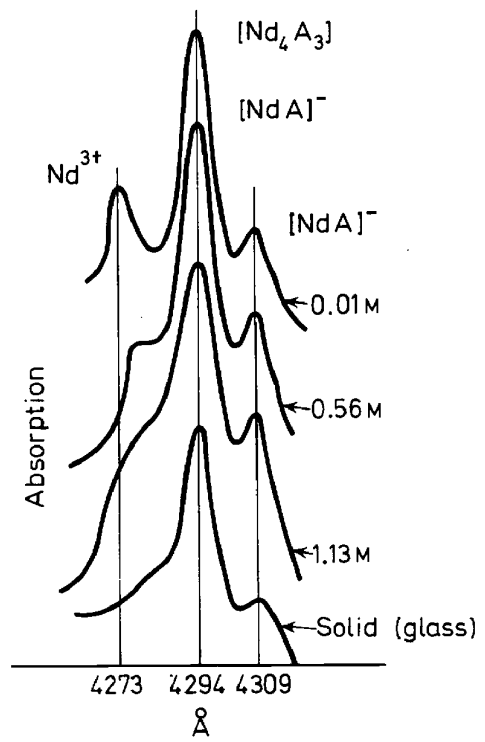

Figure 4. Absorption spectra of aqueous solutions of $\mathrm{Nd}[\mathrm{NdA}]_{3}(\mathrm{pH}=5.5)$ at various concentrations of uncomplexed $\mathrm{Nd}^{3+}$ (g-ion/l.). 
carriers from solution to ionite. Particularly valuable in this respect (fast 'resin-solution' exchange) are rare earth derivatives of hydroxycarboxylic acids. Therefore, introduction of hydroxycarboxylic acids into solutions of rare earth complexonates promotes significantly the establishment of equilibrium in the system and improves the separation efficiency ${ }^{51}$.

Although it follows from the infra-red spectra ${ }^{52}$ that in lanthanide complexonates the $\mathbf{L n}-\mathrm{N}$ bond is of a somewhat ionic nature, there is no doubt that its deviation from covalency is very small. As is clear from Figure 4, the concentrating of $\mathrm{Nd}[\mathrm{NdA}]_{3}$ solutions involves a change in the absorption spectra-the absorption band of uncomplexed neodymium disappears and there remains only the band belonging to the monoderivative $[\mathrm{NdA}]^{-}$. Thus, a second sphere neodymium can be complexed by ethylenediaminetetraacetic acid already bound into a complexonate. The symmetry of the monoderivative being preserved in this case, it can be concluded that there is an equivalent position of all neodymium atoms in $\mathrm{Nd}_{4} \mathrm{~A}_{3}$ and that the neodymium-complexon bond has an ionic character ${ }^{53}$.

A number of important studies in the chemistry of complex compounds of rare earths has been carried out at the laboratory headed by Yatsimirsky. Of great interest is a systematic investigation of rare earth gluconates published by Kostromina ${ }^{54}$ and the studies of beta-diketonates instituted by Davydenko 55,56 . Worthy of notice also is a comparative study of the thermodynamic characteristics of rare earth coordination compounds in terms of crystal field theory and ligand field theory carried out by Yatsimirsky and collaborators ${ }^{57,58}$.

Very interesting results were obtained at the above mentioned laboratory in the study of the absorption (aqueous solutions) and reflection spectra (solids) using high resolution spectrographs ${ }^{59}$. For neodymium, europium, and sometimes erbium compounds, the use of such instruments instead of ordinary spectrophotometers made it possible to determine directly from spectra the number of complexes present in the sample being studied and also to estimate the stability of a complex in aqueous solution ${ }^{56,60}$. Sometimes it is possible from the relative shift of the absorption bands to determine the type of bond in complexes and the number of coordinated donor groups of the ligand ${ }^{57,61,62}$.

A large number of new data were obtained by Kostromina in investigations of rare earth complexonates by n.m.r. spectroscopy ${ }^{63}$. In particular, she showed that in the La-Y-Lu series a change occurs in the geometry of complexonates as well as in the nature of the bonds with different donor atoms and in their mobility values.

The chemistry of a radioactive representative of the lanthanide family, promethium, has been rather scantily studied. In this connection, the work carried out by Brezhneva and collaborators is to be noted ${ }^{64}$. The investigation was conducted on a relatively long-lived promethium-147 isotope $\left(T_{\frac{1}{2}}=\right.$ 2.6 year). The distribution of promethium between the oxyne solution in chloroform and a $0.1 \mathrm{~N} \mathrm{NaClO}_{4}$ solution was studied at various $\mathrm{pH}$ values. This enabled the stability constants of promethium oxynates $\left(\mathrm{MeA}_{3}, \mathrm{MeA}_{2}^{+}\right.$ and $\mathrm{MeA}^{2+}$ ) to be calculated. They were found to have intermediate values, as compared with similar lanthanum and samarium complexes, but are closer to lanthanum. 
In our laboratory considerable contributions to the chemistry of coordination compounds of scandium have been made by Komissarova and collaborators. The complex compounds of scandium based on its nitrate were first obtained. These are molecular adducts $\mathrm{Sc}\left(\mathrm{NO}_{3}\right)_{3} \cdot 2 \mathrm{R}$, where $\mathbf{R}$ is $\mathrm{HNO}_{3}, \frac{1}{2} \mathrm{~N}_{2} \mathrm{O}_{5}, \frac{1}{2} \mathrm{~N}_{2} \mathrm{O}_{4}$, aromatic amines) and complexes of composition $\mathrm{Me}_{2}\left[\mathrm{Sc}\left(\mathrm{NO}_{3}\right)_{5}\right]$, where $\mathrm{Me}$ is $\mathrm{K}, \mathrm{Rb}$ or Cs. Solvates of sodium nitrate, e.g. $\mathrm{Sc}\left(\mathrm{NO}_{3}\right)_{3} \cdot \mathrm{N}_{2} \mathrm{O}_{4}$ and $\mathrm{Sc}\left(\mathrm{NO}_{3}\right)_{3} \cdot \mathrm{N}_{2} \mathrm{O}_{5}$, seem to be acidocompounds of the type $\mathrm{NO}^{+}\left[\mathrm{Sc}\left(\mathrm{NO}_{3}\right)_{4}\right]^{-}$and $\mathrm{NO}_{2}^{+}\left[\mathrm{Sc}\left(\mathrm{NO}_{3}\right)_{4}\right]^{-}$.

Alkali metal-scandium nitrates are unstable and show high solubility in aqueous nitric acid solutions. Solvates with nitric acid and nitric oxides are still less stable. Only compounds with organic amines $\mathrm{Sc}\left(\mathrm{NO}_{3}\right)_{3} \cdot 2 \mathrm{Phen}$ and $\mathrm{Sc}\left(\mathrm{NO}_{3}\right)_{3} \cdot 2 \mathrm{Dip}$ (Phen denotes orthophenanthroline, Dip is dipyridyl) exhibit higher thermal stability and slight solubility in water and oxygencontaining organic solvents ${ }^{65,66}$.

Interesting results were obtained also in studies of the chemistry of rhodanide compounds of scandium, not yet described in the literature. It was shown that scandium forms with the rhodano group several types of coordination compounds :

1 Tetrarhodano scandiates of alkali metals, rare earths and ammonium: $\mathrm{M}^{\mathrm{I}}\left[\mathrm{Sc}(\mathrm{NCS})_{4}\right] \cdot n \mathrm{H}_{2} \mathrm{O}$ or $\mathrm{M}^{\mathrm{II}}\left[\mathrm{Sc}(\mathrm{NCS})_{4}\right]_{2} \cdot n \mathrm{H}_{2} \mathrm{O}$

2 Hexarhodano scandiates of alkali metals, rare earths, ammonium and organic bases, $\mathrm{M}_{3}\left[\mathrm{Sc}(\mathrm{NCS})_{6}\right] \cdot n \mathrm{H}_{2} \mathrm{O}$

3 Molecular adducts with oxygen- and nitrogen-containing organic compounds $\mathrm{Sc}(\mathrm{NCS})_{3} \cdot n \mathrm{R}(n=2 \text { or } 3)^{67}$.

In all the compounds listed the rhodano group is coordinated through a nitrogen atom, and scandium shows the coordination numbers four, six and higher. The compounds with the coordination number four are much less

Table 2. Correlation of the formation constants $\left(\beta_{1}\right)$ and instability constants $\left(K_{1}\right)$ of hydroxo complexes of some rare earth elements

\begin{tabular}{lcc}
\hline \multicolumn{1}{c}{ Element } & $\beta_{1}$ & $\boldsymbol{K}_{1}$ \\
\hline Scandium & $8.9 \times 10^{-5}$ & $7.7 \times 10^{-23}$ \\
Yttrium & $6.1 \times 10^{-6}$ & $1.4 \times 10^{-16}$ \\
Erbium & $9.2 \times 10^{-6}$ & $3.9 \times 10^{-18}$ \\
Ytterbium & $2.5 \times 10^{-5}$ & $7.8 \times 10^{-19}$ \\
Lutetium & $9.2 \times 10^{-5}$ & $3.2 \times 10^{-19}$ \\
\hline
\end{tabular}

stable. Some rhodanide complexes were used for practical purposes (separation of scandium from impurities by extraction, quantitative separation of scandium as a sparingly soluble complex $\left[\left(\mathrm{C}_{2} \mathrm{H}_{5}\right)_{4} \mathrm{~N}\right]_{3}\left[\mathrm{Sc}(\mathrm{NCS})_{6}\right]$ in the presence of large amounts of $\mathrm{Mg}, \mathrm{Ca}, \mathrm{Al}$ and rare earth elements).

To conclude this section, it should be noted that Ivanov-Emin and co-workers studied the formation of anion hydroxo complexes in connection with the problem of the amphoteric character of rare earths. The results 
obtained have been summarized ${ }^{68}$. Some of the data from this work are listed in Table 2.

In the sequence $S c$ to $Y$ the strength of hydroxo complexes diminishes and in the sequence $\mathrm{Y}-\mathrm{Yb}-\mathrm{Lu}$ increases, which is in agreement with the order of change of the ionic radii of rare earths. Indium shows a more marked tendency to form anionic hydroxo complexes than scandium. As regards the value of $\beta_{1}$ thallium is close to ytterbium, but has a lower $K_{1}$ even than scandium, which is in agreement with the position of these elements in the Mendeleev Periodic Table.

\section{COMPLEX COMPOUNDS OF ACTINIDES}

The chemistry of complex compounds of uranium and thorium has long attracted the attention of scientists in the USSR. At the turn of the century, bearing in mind the role of uranium in the discovery of radioactivity, Mendeleev wrote: 'Being convinced that the investigation of uranium. . . will lead to many more new discoveries, I make bold to recommend to those who are looking for subjects of new studies to devote particular attention to uranium compounds...69.

The discovery in 1940 by MacMillan, Seaborg and their collaborators ${ }^{70}$ of the first transuranium elements-neptunium and plutonium and shortly after other representatives of this series of synthesized elements-led to the development of new techniques for the study of complex compounds: the carrier technique and the radioactive tracer technique. It is not an exaggeration to say that in a few years the chemistry of coordination compounds of plutonium was more thoroughly investigated than the chemistry of many ordinary elements. Often only trace quantities of these elements were used in such studies. Close cooperation between radiochemists and chemists engaged in the study of complex compounds is characteristic of this field of research.

The founder of the Soviet radiochemical school, Khlopin, was a pupil. of Chugaev and his first works were concerned with the chemistry of complex compounds ${ }^{71}$. Many Soviet scientists came to work in radiochemistry having already considerable experience in coordination chemistry, as for example, Cherniayev's pupils, Gel'man, Golovnia and others. The. radiochemical methods, in their turn, were successfully used as early as forty years ago for the investigation of unstable complex compounds. In particular, Nikitin ${ }^{72}$, making use of the co-precipitation laws, established the existence of coordination compounds of radon and other inert gases with water and organic substances, e.g. $\mathrm{Rn} \cdot 6 \mathrm{H}_{2} \mathrm{O}, \mathrm{Xe} \cdot 3 \mathrm{C}_{6} \mathrm{H}_{5} \mathrm{OH}, \mathrm{Rn} \cdot 3 \mathrm{C}_{6} \mathrm{H}_{5} \mathrm{OH}$, $\mathrm{Rn} \cdot 3 \mathrm{ClC}_{6} \mathrm{H}_{4} \mathrm{OH}$ etc.

In the past ten years Soviet scientists have synthesized and studied more than 200 new coordination compounds of thorium. A large contribution to this study was made by Molodkin and his co-workers ${ }^{73-76}$. Various classes of thorium complexes were studied in detail. On the basis of preparative, thermogravimetric, spectroscopic, $x$-ray diffraction and other investigations, it was conclusively proved that thorium has no constant coordination number. It can vary within one class of compounds. Thorium complexes isolated from solution show high (from 8 to 12 , possibly over 12) coordination number: 


\begin{tabular}{lc}
\hline \multicolumn{1}{c}{ Compound } & $\begin{array}{c}\text { Coordination } \\
\text { number of } \\
\text { thorium }\end{array}$ \\
\hline$\left[\mathrm{Th}\left(\mathrm{SO}_{4}\right)_{2}\left(\mathrm{H}_{2} \mathrm{O}\right)_{4}\right]$ & 8 \\
$\left(\mathrm{CN}_{3} \mathrm{H}_{6}\right)_{2} \mathrm{Th}\left(\mathrm{SO}_{4}\right)_{3}\left(\mathrm{H}_{2} \mathrm{O}\right)_{3} \cdot 3 \mathrm{H}_{2} \mathrm{O}$ & 9 \\
$\left.\left[\mathrm{Th}^{2} \mathrm{CH}_{3} \mathrm{COO}\right)_{4}\right]$ & 10 \\
$\left(\mathrm{CN}_{3} \mathrm{H}_{6}\right)_{2}\left[\mathrm{Th}\left(\mathrm{CH} \mathrm{CHOO}_{6} \mathrm{COO}\right]\right.$ & 12 \\
\hline
\end{tabular}

The type of coordination by thorium of these or other ligands depends mainly on their nature. If the nitrato and oxalato groups in thorium compounds are characterized by a bidentate cyclic function, the formato groups show bridging and the rhodano groups exhibit a monodentate function and are attached to thorium through a nitrogen atom. In carbonate, acetate and especially in sulphate compounds, the coordination by thorium of acido groups is quite varied.

It was shown that a considerable number (up to 12) of neutral molecules (carbamide and dimethylsulphoxide) can be incorporated in the inner sphere of complexes at the expense of displacement of water molecules and acido ligands. For aqueous solutions the following sequence of mutual displacement of ligands from the inner sphere of thorium compounds was established: $\mathrm{OH}^{-}>\mathrm{CO}_{3}^{2-}>\mathrm{C}_{2} \mathrm{O}_{4}^{2-}>\mathrm{SO}_{3}^{2-}>\mathrm{CH}_{3} \mathrm{COO}^{-}>\mathrm{HCOO}^{-}>\mathrm{SO}_{4}^{2-}>$ $\mathrm{SCN}^{-}>\mathrm{NO}_{3}^{-}>\mathrm{Cl}^{-}$. This scheme facilitates the search for synthesis conditions of new complex compounds of thorium.

A great many studies of the chemistry of coordination compounds of uranium have been carried out. Cherniayev, Golovnia and their collaborators have synthesized many new acido complexes of uranyl and tetravalent uranium derivatives ${ }^{77}$. The coordination number of uranium was found to be four, five and six. For instance, the compounds, $\left[\mathrm{UO}_{2}\left(\mathrm{CO}_{3}\right)_{3}\right]^{4-}$, $\left[\mathrm{UO}_{2}\left(\mathrm{CH}_{3} \mathrm{COO}\right)_{3}\right]^{-},\left[\mathrm{UO}_{2}\left(\mathrm{C}_{2} \mathrm{O}_{4}\right)_{3}\right]^{4-}$, in which all ligands are bidentate,

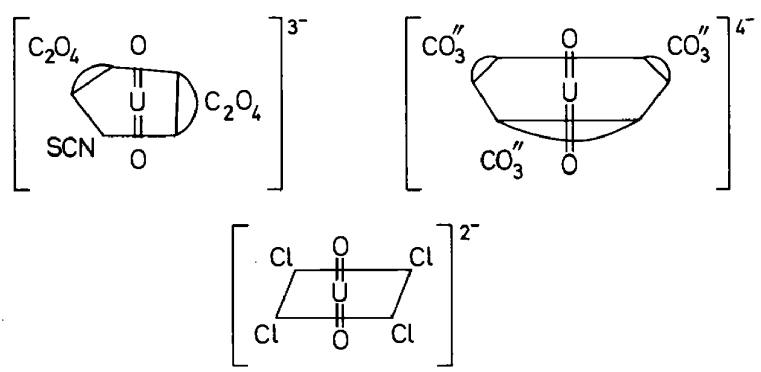

Figure 5. Scheme of structure of complex uranyl compounds.

lying in a plane perpendicular to the uranyl axis, have the coordination number six.

The saturated compounds with respect to fluorine are uranyl pentafluoride, $\left[\mathrm{UO}_{2} \mathrm{~F}_{5}\right]^{3-}$, or aquotetrafluoride, $\left[\mathrm{UO}_{2} \mathrm{~F}_{4} \mathrm{H}_{2} \mathrm{O}\right]^{2-}$, where the coordination number of uranyl is five. Pentacoordinated complexes are also acetato- 
chloride $\left[\mathrm{UO}_{2}\left(\mathrm{CH}_{3} \mathrm{COO}\right) \mathrm{Cl}_{3}\right]^{2-}$, aquodioxalate $\left[\mathrm{UO}_{2}\left(\mathrm{C}_{2} \mathrm{O}_{4}\right)_{2} \mathrm{H}_{2} \mathrm{O}\right]^{2-}$, rhodanidodioxalate $\left[\mathrm{UO}_{2}\left(\mathrm{C}_{2} \mathrm{O}_{4}\right)_{2} \mathrm{NCS}\right]^{3-}$, trifluoroacetate $\left[\mathrm{UO}_{2} \mathrm{~F}_{3}\right.$ $\left.\left(\mathrm{CH}_{3} \mathrm{COO}\right)\right]^{2--}$ etc., which have five bonds. In the case of chloride or bromide complex compounds, the coordination number of uranyl drops to four $\left[\mathrm{UO}_{2} \mathrm{Cl}_{4}\right]^{2-},\left[\mathrm{UO}_{2} \mathrm{Br}_{4}\right]^{2-},\left[\mathrm{UO}_{2} \mathrm{Cl}_{2} \mathrm{Br}_{2}\right]^{2-}$. Figure 5 shows schematically the structure of some complex compounds of uranyl.

Tetravalent uranium has the coordination number eight. It is characterized mainly by distorted cubic structures of complex compounds ${ }^{78}$. The ligands are located at the apexes of such cubes. Apparently they show different bond strengths, and this is responsible for the tendency of uranium(Iv) complex compounds to form chain or laminated polymers (Figure 6).

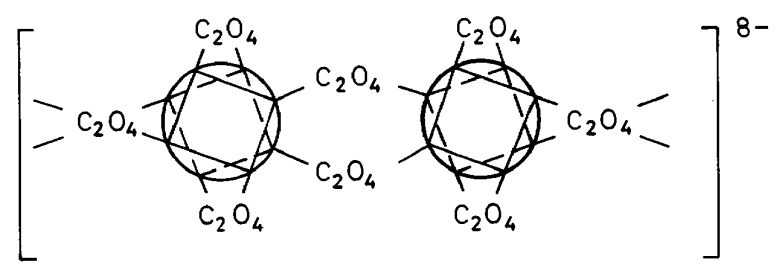

Figure 6. Scheme of structure of binuclear tetraoxalatouranium (IV).

On the basis of the syntheses carried out, the genetic series of complex uranium compounds were predicted. These genetic series were synthesized with ligands of the following composition : carbonates, hydroxocompounds, fluorides, acetates, oxalates, chlorides, nitrates, sulphates, rhodanides etc.

An important role in the progress of synthetic studies being considered was played by the arrangement of ligands in a series according to their ability to displace one another from the inner sphere of complex uranium compounds. This made it possible to carry out synthesis of compounds of desired composition and in a number of cases to predict some of their properties. Below is given an abridged series of acido ligands, arranged according to their diminishing activity: $\mathrm{CO}_{3}^{2-}>\mathrm{OO}^{2-}>\mathrm{OH}^{-}>\mathrm{F}^{-}>\mathrm{CH}_{3} \mathrm{COO}^{-}$ $>\mathrm{C}_{2} \mathrm{O}_{4}^{2-}>\mathrm{SO}_{4}^{2-}>\mathrm{SCN}^{-}>\mathrm{CI}^{-}>\mathrm{NO}_{3}^{-}>\mathrm{Br}^{-}>\mathrm{I}^{-}$. A thorough investigation of the use of the ligand series arranged according to their displacing ability led to synthesis of complex uranium compounds with inner sphere ligands of varying composition. Below are given some of the complexes obtained:

$$
\begin{aligned}
& \left(\mathrm{NH}_{4}\right)_{4}\left[\left(\mathrm{UO}_{2}\right)_{2}\left(\mathrm{C}_{2} \mathrm{O}_{4}\right)\left(\mathrm{SO}_{4}\right)_{2}(\mathrm{SCN})_{2}\right] \cdot 6 \mathrm{H}_{2} \mathrm{O} \\
& \left(\mathrm{NH}_{4}\right)_{4}\left[\left(\mathrm{UO}_{2}\right)_{2}\left(\mathrm{C}_{2} \mathrm{O}_{4}\right)_{2}\left(\mathrm{SO}_{4}\right)(\mathrm{SCN})_{2}\left(\mathrm{H}_{2} \mathrm{O}\right)_{2}\right] \\
& \mathrm{K}_{3}\left[\mathrm{UO}_{2}\left(\mathrm{CO}_{3}\right) \mathrm{F}_{3}\right] \\
& \left(\mathrm{CN}_{3} \mathrm{H}_{6}\right)_{2}\left[\mathrm{UO}_{2}\left(\mathrm{CO}_{3}\right) \mathrm{F}_{2}\left(\mathrm{H}_{2} \mathrm{O}\right)_{2}\right] \\
& \mathrm{Rb}_{3}\left[\mathrm{UO}_{2} \mathrm{~F}\left(\mathrm{C}_{2} \mathrm{O}_{4}\right)_{2} \cdot \mathrm{H}_{2} \mathrm{O}\right] \\
& \left(\mathrm{NH}_{4}\right)_{2}\left[\mathrm{UO}_{2}\left(\mathrm{CO}_{3}\right)\left(\mathrm{C}_{2} \mathrm{O}_{4}\right)\left(\mathrm{H}_{2} \mathrm{O}\right)_{2}\right]
\end{aligned}
$$

The coordination compounds formed in uranium extraction by organic solvents were studied by Vdovenko and collaborators ${ }^{79}$. For a classical 


\section{I. SPITSYN}

system, aqueous uranyl nitrate solution-diethylether, they suggested that solubility of the uranyl salt hydrate in ether is associated with formation of a hydrogen bond between two water molecules bound to uranium and ether molecules (Figure 7). With decreasing proton-accepting properties of ether (in the sequence diethyl-, $n$-dibutylether etc.), this interaction diminishes and so does the solubility of uranyl nitrate.

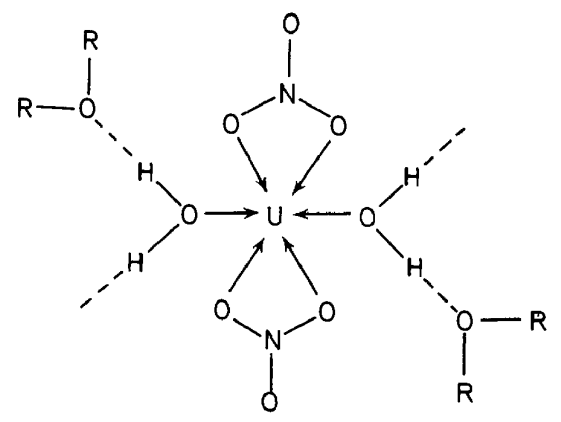

Figure 7. Structure of the coordination sphere of uranium in ether solutions of uranylnitrate dihydrate.

Increase of the degree of hydration of uranyl nitrate decreases its solubility in ether, which, according to the authors of the above mentioned studies, is due to the substitution of ether by water in the second solvate layer following the scheme:<smiles>[R]ONO[R]</smiles>

(2)

High miscibility of solvate of type (2) with ethers comparable with the solubility of solvate of type (1) is possible only in the solvents in which the solubility of water itself is high enough, e.g. in ethylether ${ }^{80}$.

Numerous studies of the complex compounds of actinides were carried out by Gel'man and co-workers. Their earlier results have been published ${ }^{\mathbf{8 1}}$. Later on, this team of scientists centred their attention on the investigation of the coordination compounds of actinides in relatively unstable valent forms-uranium(III), neptunium(v) and (III), plutonium(v), as well as on the synthesis and study of the properties of mixed complexes of these elements with some ligands.

It was established that trivalent uranium, thermodynamically unstable in aqueous solutions, is significantly more stable when isolated as some solid complex compounds ${ }^{82,83}$. Thus, anhydrous compound $\mathrm{K}_{5} \mathrm{U}\left(\mathrm{SO}_{4}\right)_{4}$, isostructural with respect to similar rare earth compounds and trivalent actinides, is stable on prolonged storage in air. It is formed as a heavy 
crystalline precipitate when excess of potassium sulphate is added to a sulphate solution of uranium(III). Trivalent neptunium behaves similarly to uranium.

Interesting results were obtained in the investigation of the complexing of oxygen-containing cations of neptunium in different valence forms with sulphate ions ${ }^{84}$. It proved that in the cation sequence: $\mathrm{NpO}_{2}^{+}-\mathrm{NpO}_{2}^{2+}-\mathrm{NpO}_{2}^{3+}$ the change in the charge, even if it leads to a regular increase in stability of complex sulphates, is not as sharp as would be expected by analogy with the well-known influence of the charge on the stability of complexes in the case of trivalent and tetravalent actinides. Increased tendency of $\mathrm{NpO}_{2}^{+}$to complex with the $\mathrm{SO}_{4}^{2-}$ ion is responsible for the fact that neptunium(v) is easily isolated from neutral sulphate solution in the form of crystalline compounds containing two or more $\mathrm{SO}_{4}$ groups in the metal coordination sphere. On the other hand, the stability constants of neptunium(v) complexes with one or two sulphate groups are only two to five times higher than the stability constants of the corresponding neptunium(vi) complexes.

Recently Gel'man and collaborators confirmed an anomalously high tendency of neptunium(v) to form coordination compounds, as evidenced by synthesis of crystalline products of composition: $\mathrm{MeNpO}_{2} \mathrm{C}_{2} \mathrm{O}_{4} \cdot n \mathrm{H}_{2} \mathrm{O}$, where $\mathrm{Me}$ is $\mathrm{Na}, \mathrm{K}, \mathrm{Cs}, \mathrm{NH}_{4}$ and $n$ is $1-3 ; \mathrm{Co}\left(\mathrm{NH}_{3}\right)_{6} \mathrm{NpO}_{2}\left(\mathrm{C}_{2} \mathrm{O}_{4}\right)_{2} \cdot 3 \mathrm{H}_{2} \mathrm{O}$, $\mathrm{Co}\left(\mathrm{NH}_{3}\right)_{6} \mathrm{NpO}_{2} \mathrm{Y}$ and $\left(\mathrm{NpO}_{2}\right)_{2} \mathrm{H}_{2} \mathrm{Y} \cdot 5 \mathrm{H}_{2} \mathrm{O}$, where $\mathrm{Y}$ is a quadruply charged anion of ethylenediaminetetraacetic $\mathrm{acid}^{85}$.

Increased tendency to form coordination compounds is characteristic not only of neptunium, but also of other pentavalent actinides. This was confirmed by investigations of plutonium(v) complexing with various ligands ${ }^{86}$. In spite of a limited stability of plutonium(v) in aqueous solution, its compounds with oxalate-, fluoride-, phosphate- and ethylenediaminetetraacetate ions were isolated in the pure form.

\section{COMPLEX COMPOUNDS OF ELEMENTS OF VARIOUS GROUPS OF THE PERIODIC SYSTEM}

The studies of Soviet scientists in coordination chemistry cover practically the whole Periodic System. Here we shall dwell but briefly only on certain important results of the studies in the chemistry of the complex compounds of some elements.

Novoselova and co-workers ${ }^{87}$ obtained beryllium alkoxyacetates of type $\mathrm{Be}(\mathrm{OR}) \mathrm{OCOCH}$, readily soluble in organic solvents where $\mathrm{R}$ is $\mathrm{CH}_{3}, \mathrm{C}_{2} \mathrm{H}_{5}$, $\mathrm{C}_{3} \mathrm{H}_{7}$ or $\mathrm{C}_{4} \mathrm{H}_{9}$, which proved to be coordination polymers :

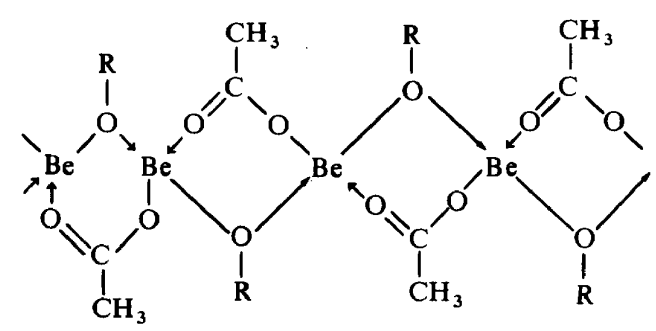




\section{I. SPITSYN}

Thermal decomposition of these compounds readily gives sublimable low-molecular products of composition $\mathrm{Be}_{4} \mathrm{O}\left(\mathrm{OCOCH}_{3}\right)_{5} \mathrm{OR}$, which are close analogues of well-known beryllium oxyactetate.

In our laboratory studies were carried out on complex compounds of boron halides with amines and phosphines. The nature of the boronnitrogen and boron-phosphorus bonds can be varied by introduction of different substituents, enhancing the tendency of the adducts to disproportionation, dehydrogenation and polymerization. Thus, for example, complexes of boron trifluoride with primary amines of the type $\mathrm{BF}_{3} \cdot \mathrm{NH}_{2}\left(\mathrm{C}_{2} \mathrm{H}_{5}\right)$ were used ${ }^{88}$ for synthesis of boron-containing polymers. Dehydrogenation reactions were carried out, e.g. $\mathrm{BF}_{3} \cdot \mathrm{NH}_{2}^{2}\left(\mathrm{C}_{2} \mathrm{H}_{5}\right)=$ $\left(\mathrm{BF} \cdot \mathrm{NC}_{2} \mathrm{H}_{5}\right)+2 \mathrm{HF}$, yielding, along with trimer derivatives, polymeric compounds with high adhesion properties.

Complex compounds of the type $\mathrm{BF}_{3}, \mathrm{PR}_{3}$, where $\mathrm{R}$ is alkyl or aryl, were also examined ${ }^{89}$. Dipole moment measurements showed that interaction of boron trifluoride with phosphine derivatives leads to the appearance of a donor-acceptor bond favouring polymerization. It was shown by a calorimetric titration method that the boron-phosphorus bond is somewhat less strong than the boron-nitrogen bond in similar adducts with amines.

Deichman and collaborators ${ }^{90}$ synthesized and studied fluoride, fluorosulphate and phosphate complex compounds of indium, e.g. $\left(\mathrm{NH}_{4}\right)_{2}\left[\operatorname{InSO} \mathrm{I}_{4} \mathrm{~F}_{3} \cdot \mathrm{H}_{2} \mathrm{O}\right], \quad \mathrm{Rb}_{4}\left[\operatorname{In}_{2}\left(\mathrm{SO}_{4}\right)_{3} \mathrm{~F}_{4}\left(\mathrm{H}_{2} \mathrm{O}\right)_{2}\right], \quad\left(\mathrm{NH}_{4}\right)_{3}\left[\operatorname{In}\left(\mathrm{PO}_{4}\right)_{2}\right] \cdot$ $\mathrm{H}_{2} \mathrm{O}$ etc. All the compounds obtained are readily hydrolysable in aqueous solution.

The complexing reactions of zirconium and hafnium have also received much attention. Using the ion exchange method, Riabchikov, Ermakov and co-workers ${ }^{91,92}$ investigated the interaction of these elements with complexons and other organic and inorganic ligands. It was found that the stability of zirconium and hafnium complexes with inorganic ligands diminishes in the sequence:

$$
\mathrm{OH}^{-}>\mathrm{F}^{-} \gg \mathrm{SO}_{4}^{2-} \gg \mathrm{Cl}^{-}, \mathrm{NO}_{3}^{-}
$$

Synthesis and investigation of new coordination compounds of transition metals, including polynuclear and mixed compounds have been given much attention in the USSR. A number of interesting studies in this field were carried out by Ablov and collaborators. For example, they investigated the adducts of quinoline, pyridine and their derivatives with copper salts of acetic acid and substituted acetic acids. Compounds of the type $\left(\mathrm{CH}_{3} \mathrm{COO}\right)_{4} \mathrm{Cu}_{2} \cdot 2 \mathrm{C}_{5} \mathrm{H}_{5} \mathrm{~N}$ were obtained, in which two copper ions lie close to one another and enter into direct exchange with each other ${ }^{93}$. Also among these binuclear complexes are adducts of copper(II) salycilate and oxygen-containing molecules: alcohols, dioxane and dimethylformamide ${ }^{94}$.

Copper(II) compounds with selenosemicarbazide proved to be chelate complexes in which two coordinated selenosemicarbazide molecules lie in the same plane ${ }^{95}$. 


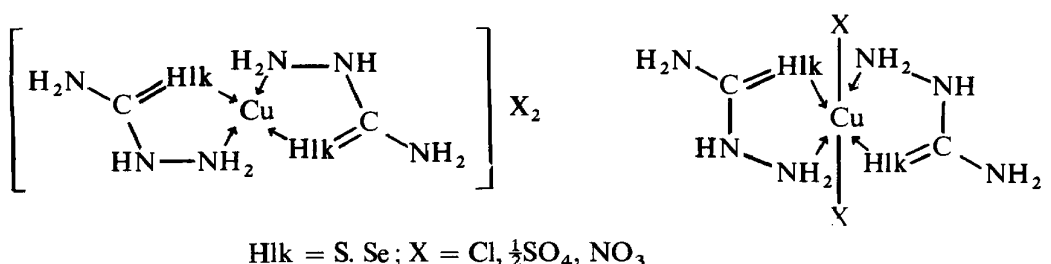

$\mathrm{Hlk}=\mathrm{S} . \mathrm{Se} ; \mathrm{X}=\mathrm{Cl}, \frac{1}{2} \mathrm{SO}_{4}, \mathrm{NO}_{3}$

New coordination compounds of cobalt(III) and iron(II, III) with various $\pi$-ligands were synthesized ${ }^{96}$. As exemplified by cobalt(III), it was shown that in the case of its trans-dioxyimines the ligands are added to the central atom through sulphur or selenium. With cis-dioxyimines coordination of thiocyanate and selenocyanate ions localized in the inner sphere occurs through nitrogen:<smiles>NC1=NN2C=[Ge](Oc3ccccc3C=O)C(Oc3ccccc3)(N1)Oc1ccccc1C=[Se]2</smiles>

Pliushchev and collaborators ${ }^{97,98}$ are currently engaged in research on polynuclear complex halide compounds and polyhalides. They have studied many polynuclear complexes of composition $\mathrm{Cs}_{3} \mathrm{Sb}_{2} \mathrm{Cl}_{9}, \mathrm{Rb}_{7} \mathrm{Sb}_{3} \mathrm{Cl}_{16}$, $\mathrm{K}_{2} \mathrm{SbCl}_{5}, \mathrm{Cs}_{3} \mathrm{Sb}_{2} \mathrm{Br}_{9}, \mathrm{Rb}_{3} \mathrm{BiCl}_{6}, \mathrm{~K}_{2} \mathrm{BiBr}_{5}$ etc. For many systems of the type $\mathrm{MX}-\mathrm{AX}_{3}-\mathrm{HX}-\mathrm{H}_{2} \mathrm{O}(\mathrm{M}=\mathrm{K}, \mathrm{Rb}, \mathrm{Cs} ; \mathrm{A}=\mathrm{Sb}, \mathrm{Bi} ; \mathrm{X}=\mathrm{Cl}, \mathrm{Br}, \mathrm{I})$ they determined the possible number and composition of all halogeno complexes that can be isolated from aqueous solutions of respective halogen hydracids.

The same authors ${ }^{99}$ investigated the conditions of synthesis in different media of polyhalides of general composition $\mathrm{M}\left[\mathrm{X}_{n}^{\mathrm{I}} \mathrm{X}_{m}^{\mathrm{II}} \mathbf{X}_{k}^{\mathrm{III}}\right]$, where $\mathrm{M}$ is the alkali element cation, and $X^{I}, X^{I I}, X^{\text {III }}$ various halogens forming a complex singly charged anion and acting as the central atom and ligands. As a rule, $n+m+k=3,5,7$ or 9 . No compounds with four different halogens are known. It is possible to prepare polyhalides with sharply different stability or solubility containing potassium, rubidium and caesium. Among them is the compound $\mathrm{Cs}[\mathrm{I}(\mathrm{IBr})]$, which has no analogues, and compounds $\mathrm{M}\left[\mathrm{I}\left(\mathrm{I}_{2}\right)\right]$, where $\mathrm{M}$ is $\mathrm{Rb}$ or Cs.

In the inert gases family, Nikolaev and collaborators ${ }^{100}$ studied the solubility of xenon di-and tetra-fluoride in various inorganic fluorine-containing media. A complex compound of composition $\mathrm{XeF}_{4} \mathrm{IF}_{5}$ was isolated for the first time. 


\section{I. SPITSYN}

\section{NEW TYPES OF LIGANDS}

Recently, much attention has been given to the problem of polymer complexing. The interest in this problem can be readily understood when we take into consideration such aspects of complexing at the macromolecular level as chelate-forming ion exchange, polymer complexonometry, heterogeneous catalysis by means of polymer coordination compounds, etc. In the Soviet Union two fundamentally different classes of polymer complex compounds were obtained and investigated: (a) polycoordination of polyvalent ions with polydentate low molecular ligands gave macromolecules, the main chain of which contains metal ions and breaks upon their removal: -(M)-(M)-(M)- ( (b) coordination of polyvalent ions with previously synthesized macromolecular ligands gave macromolecules containing metal ions in side branches : $\frac{}{(M)}(\mathrm{M})(\mathrm{M})$. In this case a metal is easily removed or replaced by another one without breaking the main chain.

The regularities of the polycoordination reaction of the first type were investigated by Korshak and Vinogradova and collaborators ${ }^{101}$. They carried out polycoordination of $4,4^{\prime}$-bis-acetoacetyldiphenyloxide with acetylacetonates of beryllium, cobalt, copper, cadmium, nickel etc., e.g.

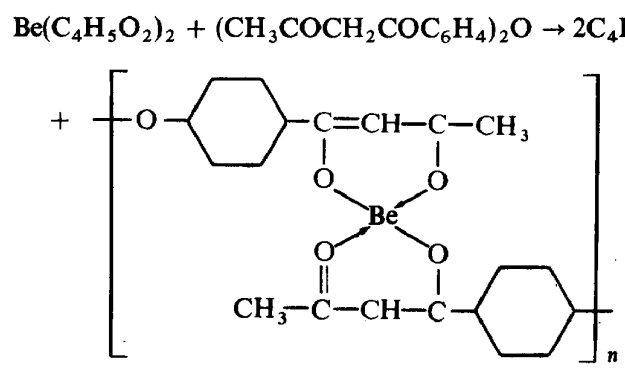

In this manner, synthesis of a large number of homogeneous and mixed coordination polymers was carried out; quinizarin, bis-oxyquinolylmethane, 4,4'-bis-acetoacetylphenyl ester and other reagents were also used as initial ligands in the latter case. Korshak and Poliakova ${ }^{102}$ also used, for synthesis of coordination polymers, the photochemical oxidative decarbonylation of metal carbonyl ( $\mathrm{Mn}, \mathrm{Fe}, \mathrm{Cr}, \mathrm{W}, \mathrm{Mo}$ ) in the presence of diphenylphosphinic, diphenylarsenic and toluenesulpho acids, according to the first scheme

$$
\mathrm{M}(\mathrm{CO})_{n}+m \mathrm{LH} \rightarrow \mathrm{ML}_{m}+n \mathrm{CO}+\frac{1}{2} m \mathrm{H}_{2}
$$

The second type of complex with macromolecular ligands of various structures (polyketoesters, poly- $\beta$-diketones, polyacrylic and methacrylic acids, etc.) was studied by Kargin, Davydova and co-workers ${ }^{103}$. As an illustration, the following compounds may be mentioned:<smiles>[R]C1(CC)O[N+](C)(C)OC1(CCC)CCC</smiles> 


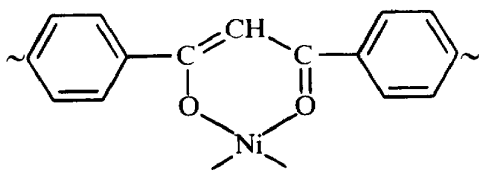

A study was also made of the reactivity of these complex compounds when used as catalysts for various oxidation, decomposition and polymerization reactions ${ }^{104}$. Hydrogenation of the enolic bond of nickel complexes of the above type under asymmetrizing conditions leads to formation of polyhydroxyesters, or polyhydroxyketones, respectively, with asymmetric C atoms in the main or side chain of the polymer ${ }^{105}$ :

$$
\begin{gathered}
\sim\left(\mathrm{CH}_{2}\right)_{m}-\stackrel{*}{\mathrm{C}} \mathrm{H}(\mathrm{OH})-\underset{\mathrm{CH}}{\mathrm{CH}}\left(\mathrm{CH}_{2}\right)_{m} \sim \\
\mathrm{COOR} \\
\sim \mathrm{CH}_{2}-\underset{\mathrm{C}\left(\mathrm{CH}_{3}\right) \sim}{1} \\
{ }^{*} \mathrm{CHOH} \\
1 \\
\mathrm{CH}_{2} \\
1 \\
\mathrm{COCH}_{3}
\end{gathered}
$$

The specific features of complex formation at the macromolecular level were considered by Davydova and Platé. Some aspects of metal ions complexing with macromolecular ligands in solutions are being studied by Tolmachev and co-workers ${ }^{106}$.

Lastovsky, Diatlova and Temkina are engaged in research on new polydentate ligands-complexons ${ }^{107}$. Particularly important are fundamentally new complexons, in which the carboxyalkyl groups are partly (or completely) substituted by alkylphosphonic groups, e.g. in diethylenetriaminepentaphosphonic acid ${ }^{108}$ :<smiles>O=P(O)(O)CN(CCN(Cc1ccccc1)CP(=O)(O)O)CCN(CCO)C[PH](=O)(=O)O</smiles>

It is characteristic of the above complexes that, unlike the carboxylcontaining analogues, they form highly stable hydrogen complexes and their coordination compounds with small volume cations (Be, $\mathrm{Ge}, \mathrm{Fe}$ ) show increased stability. They form binuclear complexes of homonuclear and heteronuclear kinds $(\mathrm{Be}, \mathrm{Al})$. This specificity of the behaviour of these complex compounds, synthesized by Kabachnik and Medved' is due to an increased number of oxygen donor atoms and the stereospecificity of the phosphorus group, whose geometry is markedly different from that of the carboxyl group.

New complexons of the benzene series ${ }^{109}$ were found to be highly selective with respect to readily hydrolysable elements-indium, gallium and ion. 


\section{I. SPITSYN}

Incorporation of these complexons into highly conjugated naphthalene, stilbene and tolan systems led to the development of new luminescent reagents, in particular for chromium (with sensitivity $8 \times 10^{-8} \mathrm{M}$ ) and for scandium (with sensitivity $2.5 \times 10^{-7} \mathrm{M}$ ), which is several orders of magnitude higher than the sensitivity of analytical methods now available. An example of these is hydroquinone-bis-methyleniminodiacetic acid:<smiles>O=C(O)CNCCN(CC(=O)O)Cc1cc(O)c(CNCCOO)cc1O</smiles>

Lastovsky and his collaborators ${ }^{110}$ have also carried out studies of mixed chelate formation. Depending on the nature of the metal and the structure and dentate type of complexon and other ligands (ammonium, pyridine, ethylenediamine), mixed compounds of different types are formed in solution: mononuclear, binuclear with the same or different metals, and also 'supercomplex' compounds. For instance, ethylenediaminetetraacetic acid and ammonia form a mixed binuclear complex with cadmium and nickel, which shows an increased stability and a certain specificity of action.

\section{COORDINATION CHEMISTRY OF ORGANOELEMENT COMPOUNDS}

Modern chemistry of organoelement compounds and particularly the chemistry of organic compounds of metals, is closely associated with coordination chemistry, and these two branches of chemistry show an ever increasing overlap and interaction. The advances made by the Soviet school of the chemistry of organoelement compounds headed by Nesmeyanov are well known. The studies of Nesmeyanov and his collaborators on the reactivity of ferrocene and other metallocenes are of essential importance for the chemistry of coordination compounds, viz. for the elucidation of the effect of the central metal atom on the properties of a coordinated organic ligand, of the influence of ligands on the redox potential of the central atom and of the transfer of the effect of one organic ligand to another through a metal atom.

The most recent studies of Nesmeyanov and his collaborators revealed some instances of exchange reactions with organic ligands in transition metal complexes, which are of great interest in coordination chemistry. Thus, it has been found ${ }^{111}$ that one of the cyclopentadienyls in ferrocene can by substituted by an arene ligand to form an arene-cyclopentadienyl-ion cation: 

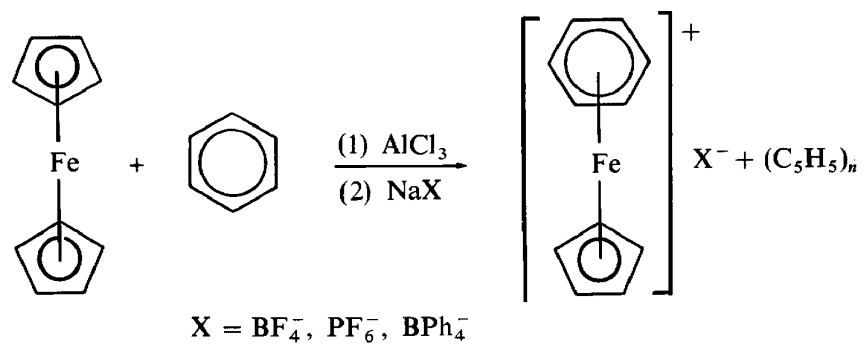

The electron-donor substituents, both in the arene and in the cyclopentadienyl rings, facilitate the process. By means of this new reaction, a large number of substituted arene-cyclopentadienyl-iron complexes were obtained and their properties investigated.

It is interesting that the action of various reducing agents (sodium amalgam, naphthalene-sodium) brings about disproportionation of these complexes to form ferrocene ${ }^{112}$ :
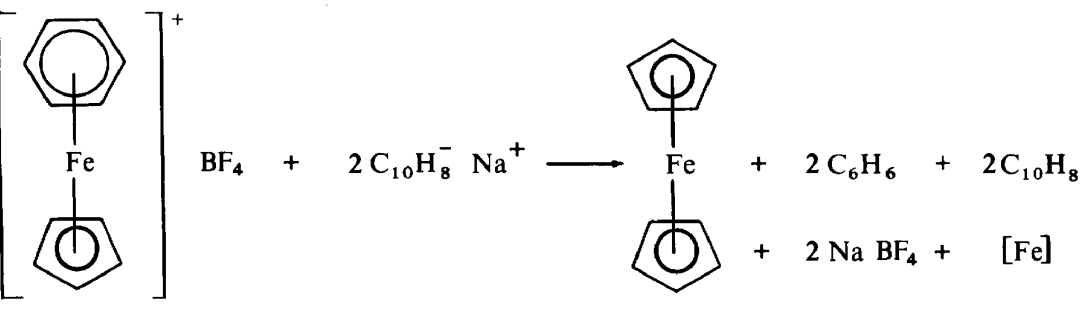

Another very interesting, and, I might say, remarkable, reaction, discovered by Nesmeyanov, Kritskaya and co-workers ${ }^{113}$, leads to trimethylene complexes of iron:

2<smiles>BrCc1ccc2ccccc2c1</smiles>

$+\mathrm{Fe}_{2}(\mathrm{CO})_{9}$

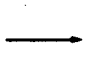

$\mathrm{Fe}(\mathrm{CO})_{3}$

To illustrate the studies of Nesmeyanov's school on $\pi$-complexes, I would like to consider some work on the diphenylacetylene complexes of niobium ${ }^{114}$, which can be represented by the following general scheme : 


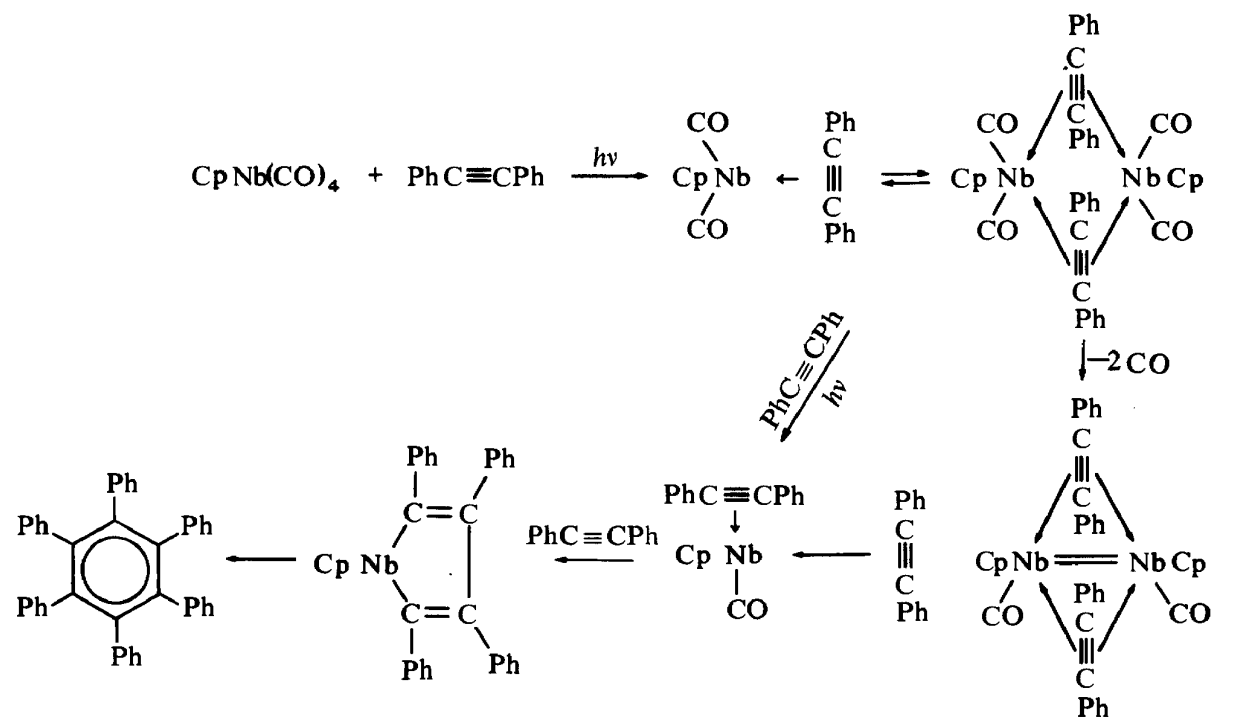

As regards the coordination chemistry of non-transition metals, the latest works of Nesmeyanov, Kravtsov et al. ${ }^{15,116}$ show the extremely important role of intra- and intermolecular coordination in molecules of mercury-, tin- and lead-organic compounds.

Reutov found that coordination through a non-transition metal atom has a significant effect on the occurrence of electrophilic substitution reactions in metallo-organic compounds. I shall not dwell here at length on these interesting studies, since they were reported by Reutov in his paper read at the plenary session of the Tenth International Conference on Coordination Chemistry ${ }^{117}$.

The work of Kocheshkov and collaborators on compounds of non-transition metals has been devoted mainly to the investigation of the principal regularities of formation and the nature of the bond in the donor-acceptor complexes with organic compounds containing heteroatoms of aromatic and unsaturated compounds. On the basis of numerous experimental results, the degree of charge transfer is found to vary in direct proportion to the strength of donor-acceptor bonds. The properties of intermolecular bonds in such complexes have been shown to depend to a considerable extent on the overlapping conditions of orbitals participating in the formation of donor-acceptor bonds. Investigation of the coordinating ability of tin-organic compounds revealed the role of the donor-acceptor interaction in the chemistry of these compounds 118,119 .

Interesting studies by Volpin and his co-workers have been concerned with another aspect of the chemistry of metallo-organic and complex compounds. The studies of Volpin on nitrogen fixation by transition metal compounds laid the foundation for this rapidly developing and interesting branch of the chemistry of coordination compounds. Soviet investigators were the first to show that molecular nitrogen can be reduced under mild 


\section{COORDINATION CHEMISTRY IN THE USSR}

conditions by various complexes of transition metal-reducing agents ${ }^{120}$, to form nitrides yielding ammonia on hydrolysis. They found that under the action of transition metal compounds, molecular nitrogen reduction can occur as a catalytic process ${ }^{121}$. Volpin also established that reactions of nitrogen with metallo-organic compounds can lead to direct synthesis of amines $^{122}$.

Important results on nitrogen fixation were also obtainèd by A. E. Shilov, who showed that by direct reaction with molecular nitrogen it is possible to obtain ruthenium and osmium complexes of nitrogen ${ }^{123}$. He also achieved important results in his studies of nitrogen fixation in aqueous solution ${ }^{124}$ and in the investigation of the mechanism of these reactions.

\section{PHYSICOCHEMICAL STUDIES OF COORDINATION COMPOUNDS}

Various physical methods are used in the USSR, in the investigation of coordination compounds. These include: ultra-violet and infra-red spectroscopy, e.s.r., n.m.r., magnetic susceptibility measurements and Mössbauer spectroscopy.

Yatsimirsky ${ }^{125}$ proposed a spectrophotometric method for the determination of stability constants, consisting of plotting some functions of optical density and ligand concentration, their extrapolation to zero or infinite ligand concentration and hence finding consecutive stability constants and molar extinction coefficients of the complexes formed in solution ('Yatsimirsky's method').

As in spectral methods, significant advances have been made in kinetic methods of the investigation of complexing. These kinetic methods have proved to be particularly applicable to the investigation of complexing in extremely dilute solutions $\left(10^{-9} 10^{-6} \mathrm{M} / 1\right.$.). These methods have made it possible to study complexing with ions giving polynuclear hydrolysis products (zirconium, hafnium, thorium, molybdenum, tungsten compounds etc. $)^{126}$, and also complexing of some metals with nucleotides and $\mathrm{DNA}^{127}$.

The techniques of studying fast reactions-abrupt stopping and relaxation method of temperature jump-have made it possible to study systematically the kinetics and mechanism of exchange reactions between polydentate ligands and lanthanide complexes. The ligand exchange rates were found to vary greatly in the lanthanide series. The existence of non-radical chain polydentate ligand exchange reactions was established for the case of complexonates of lanthanides and iron ${ }^{128}$.

Systematic studies of the elucidation of the role of coordination in homogeneous catalytic redox processes are in progress (this problem is considered in Yatsimirsky's paper (page 251 in this journal).

Nikolsky and collaborators ${ }^{129,130}$ have developed a method for studying complexing in solutions having the properties of redox systems (oxidation potential method). The great possibilities of this method were confirmed during studies not only of simple cases of complexing, but also of mixed polynuclear and heteropolynuclear complexing in aqueous and mixed solvents. The oxidation potential method was used in the investigation of the interaction of the ferricinium cation and its derivatives with $\mathrm{ClO}_{4}^{-}$, 


\section{I. SPITSYN}

$\mathrm{Cl}^{-}$and $\mathrm{SCN}^{-}$anions. Stable associates of the ferricinyl group with the $\mathrm{ClO}_{4}^{-}$anion were found to be formed ${ }^{131-133}$.

The e.s.r. method has been successfully used for investigation of coordination compounds. A strong dependence of the e.s.r. spectrum parameters of some paramagnetic ions on the nature of the ligand, discovered by Marov and Ermakov ${ }^{134,135}$, has made it possible to use e.s.r. widely for identification of complexes in solution and for determination of their composition and thermodynamic characteristics. Many problems of the chemistry of complex compounds of molybdenum(v), chromium(v) and copper(II) were successfully solved by this method. Thus, for the first time mixed coordination compounds of molybdenum were found and studied. By means of the e.s.r. method, the coexistence in solution of certain cis- and trans-isomers was established and identified and the nature of the metal-ligand bond in many coordination compounds was determined.

The proton magnetic resonance method has proved to be useful in studies of lanthanide compounds with complexon containing methylene and methyl groups. The type of coordination in complexes was found to vary significantly in the sequence lanthanum-yttrium-lutetium ${ }^{63}$. The application of the p.m.r. method to investigations of the nature of the bonding of hydrogen atoms in heteropolycompounds has already been mentioned.

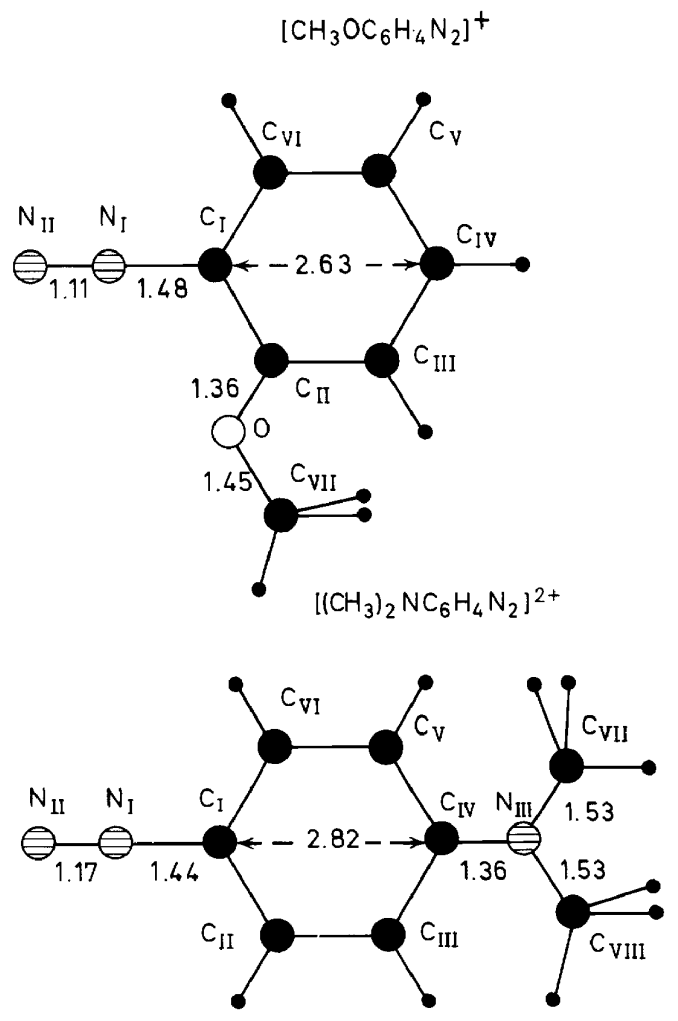

Figure 8. Structure of complex cation in crystals of double diazonium salts. 


\section{COORDINATION CHEMISTRY IN THE USSR}

Magnetic susceptibility measurements are finding ever increasing use in studies of the nature of the bonds and structure of coordination compounds. In particular, they have been used to investigate vanadium arylcarboxylates : benzoate, $o$-iodobenzoate and phenylcarboxylate. The magnetic susceptibility of these compounds proved to be somewhat greater than that for vanadyl alkylcarboxylates. This is probably associated with a decrease of $\pi$-interaction of the carboxyl group under the action of the aryl radical ${ }^{136}$.

The magnetic susceptibility of hexahalogenrhenates with different organic amines in the second sphere was measured over a wide temperature range $\left(80^{\circ}-300^{\circ} \mathrm{K}\right)$. The magnetism of these compounds was found to depend on the nature of the second sphere cation; the larger the cation size, the weaker are the antiferromagnetic properties of the compound ${ }^{137}$.

The method of $\mathrm{x}$-ray diffraction analysis has found wide use in studies of the crystal chemistry of complex compounds. Poray-Koshits and co-workers ${ }^{138,139}$ established the crystal structure of double diazo salts of composition:

$$
\begin{aligned}
& {\left[o-\mathrm{CH}_{3} \mathrm{OC}_{6} \mathrm{H}_{4} \mathrm{~N}_{2}\right]^{+} \cdot\left[\mathrm{FeCl}_{4}\right]^{-} \text {and }} \\
& {\left[o-\left(\mathrm{CH}_{3}\right)_{2} \mathrm{NC}_{6} \mathrm{H}_{4} \mathrm{~N}_{2}\right]^{2+} \cdot\left[\mathrm{ZnCl}_{4}\right]^{2-}}
\end{aligned}
$$

Here $\mathrm{Fe}$ and $\mathrm{Zn}$ atoms have a distorted tetrahedral coordination. The most important interatomic distances were determined for cations and anions of the salts under investigation (Figures 8 and 9 ).
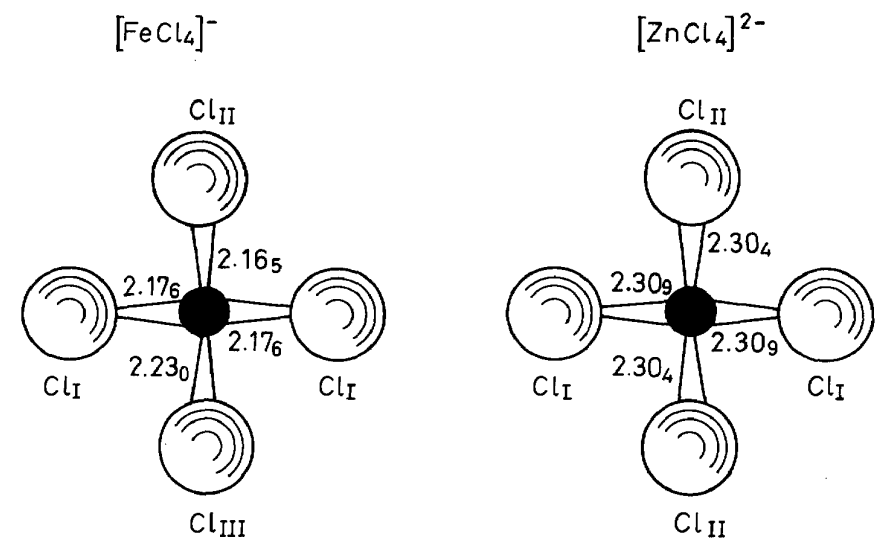

Figure 9. Structure of complex anion in crystals of double diazonium salts.

The complex salts formed by some metals with ethylene-diaminetetraacetic acid were examined by x-ray diffraction analysis. The structures of aluminium, copper, nickel, iron and magnesium compounds were established $^{140,141}$. These are exemplified by MAIA $\cdot \mathrm{H}_{2} \mathrm{O}(\mathrm{M}=\mathrm{Rb}, \mathrm{K}$, $\mathrm{NH}_{4}: \mathrm{A}=$ ethylenediaminetetraacetate), $\mathrm{K}_{2} \mathrm{CuA} \cdot 3 \mathrm{H}_{2} \mathrm{O}, \quad \mathrm{Cu}_{2} \mathrm{~A} \cdot 4 \mathrm{H}_{2} \mathrm{O}$, $\mathrm{RbCoA} \cdot 2 \mathrm{H}_{2} \mathrm{O}, \mathrm{Ni}_{3}(\mathrm{HA})_{2} \cdot 10 \mathrm{H}_{2} \mathrm{O}$ etc. Figure 10 shows the structure of the $[\mathrm{CuA}]^{2-}$ anion. 


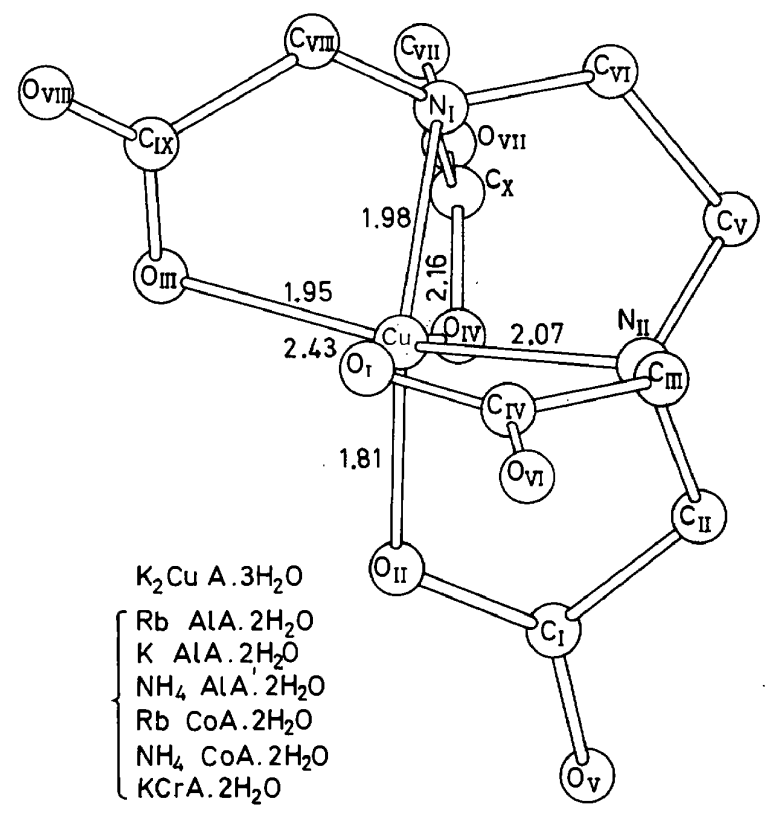

Figure 10. Structure of $[\mathrm{CuA}]^{2-}$ anion.

Syrkin, Diatkina and collaborators are engaged in research on the quantum chemistry of coordination compounds. Using non-empirical methods (Routan's method and some versions of the zero differential overlapping method) they carried out a series of calculations of molecular orbitals of aromatic complexes of metals. Aromatic rings in these complexes were shown to have negative charges and thus to undergo electrophilic substitution. Of great importance in these systems is the interaction of metal electrons with uncompleted antibonding orbitals of aromatic rings. In ferrocene the outermost completed orbit was shown to be degenerate and in dibenzene-chromium non-degenerate, which accounts for the magnetic properties of their ions [increased magnetic moment of $\left(\mathrm{C}_{5} \mathrm{H}_{5}\right)_{2} \mathrm{Fe}^{+}$ and normal magnetic moment of $\left.\left(\mathrm{C}_{6} \mathrm{H}_{6}\right)_{2} \mathrm{Cr}^{+}\right]^{142}$.

In later work ${ }^{143}$ these conclusions were confirmed by more rigorous calculation (NDDO) with the use of electronic computers.

\section{MENDELEEV PERIODIC SYSTEM AND COMPLEXING}

Soviet scientists have paid much attention to the application of the Mendeleev Periodic Law in coordination chemistry. An important contribution to this was made by Grinberg, who in his book, Introduction to the Chemistry of Complex Compounds, devoted a special section to the role of the Periodic Law in complexing ${ }^{144}$. In the last edition of his book ${ }^{145}$, 
which was published after his death, he treated this problem even more thoroughly. He particularly emphasized the presence of maxima of complexing ability in the middle of large and small periods and of minima at the ends of periods, practically at the elements of 'zero group', and immediately adjacent to them at elements of the main subgroups of groups VII and I, which are characterized by very stable electron shells.

The 'vertical' change of the complexing ability depends on the nature of the bond between the central atom and the ligands. If it is determined mainly by electrostatic factors, the complexing ability should decrease with increasing atomic number of the element. If, however, the non-electrostatic factors (covalence, $\pi$-bonds, etc.) prevail in the interaction of the central atom with coordination ligands, the opposite must be true: complexing ability will increase from top to bottom in a given subgroup.

Grinberg attempted to give quantitative criteria for assessment of the influence of the position of an element in the Periodic System on its complexing ability. For instance, on comparing the known values of the exponents of the instability constants for barium and radium complexes with $o$-phenanthroline, which for $[\mathrm{BaZ}]^{2-}=7.76$ and for $[\mathrm{RaZ}]^{2-}=7.12$, he came to the conclusion that these change approximately in inverse proportion to the ionic radii of $\mathrm{Ba}^{2+}$ and $\mathrm{Ra}^{2+}$. Grinberg thought it a very important and urgent problem to develop some methods for the approximate estimation of the expected instability constants of complexes, based on the Periodic Law.

Together with Yatsimirsky ${ }^{146}$, in order to obtain such a quantitative measure of the complexing ability, Grinberg made use of the values of the heat of reaction of the gaseous central atom with gaseous ligands.

In recent years these studies have been continued and developed by Yatsimirsky ${ }^{147,148}$. He pointed out that the phenomenon of coordination can already be observed in the first period in the case of a hydrogen bond with equivalent distances to the hydrogen atom (e.g. in $\mathrm{HF}_{2}^{-}$). However, in this case the coordination number is no higher than two and coordination is the exception rather than the rule. In the second period coordination occurs quite often, the coordination number two is repeatedly encountered, but new coordination number (two and three) appears, as well as new geometry for the coordination numbers two (bent bonds) and new types of chemical bond (not only $\sigma$, but also $\pi$ bonds). In the third period all the peculiarities of the preceding period are retained, but there appear also new types of coordination, new coordination numbers (five and six), new geometry and new types of chemical bond. The retention of the old features and the appearance of the new ones are particularly evident in the fourth period. where a stable $3 d$ shell appears for the first time.

Periodicity manifests itself in the variation of many important physicochemical parameters of coordination compounds (thermodynamical stability, kinetic characteristics, absorption spectra etc.).

Many features recur also in the case of filling of new electron shells. Thus, for instance, in the filling of $d$-shells much of what was observed in the filling of $p$-shells recurs.

In the direction along the period the number of vacant orbitals decreases, but simultaneously the energy of valence orbitals diminishes. These factors 


\section{I. SPITSYN}

act in opposite directions. Therefore, the optimum conditions for complexing are created near the middle of periods.

This review shows that in the Soviet Union studies in coordination chemistry are conducted on a large scale and cover practically all the most important problems of complexing. We clearly understood that progress in science is achieved by the efforts of scientists all over the world and that the exchange of the results of investigators in different countries is of benefit to humanity as a whole.

In preparing this communication, I wished to contribute to the noble cause of the development of mutual understanding and friendship between scientists who have come to attend the traditional International Conferences on coordination chemistry.

\section{REFERENCES}

1 L. A. Chugaev, 'Izbrannye Trudy', Vol I. Izd. Ak. Nauk SSSR: Moscow (1954).

I. I. Cherniaev, Izvest. Inst. Platiny, 4, 213 (1926).

3 A. D. Gel'man. Kompleksonye soedineniya platiny s nenasyshchennymi molekulami, Izd. Ak. Nauk SSSR : Moscow (1945).

${ }^{4}$ A. A. Grinberg, Z. Anorg. Allg. Chem. 138, 333 (1924).

5 A. A. Grinberg and G. P. Faerman. Izvest. Inst. Platiny, 8, 115 (1931):

A. A. Grinberg and G. P. Faerman. Z. Anorg. Allg. Chem. 193, 193 (1930).

'A. A. Grinberg and Kh. I. Gildengershel, Izvest. Ak. Nauk SSSR, OKHN, 479 (1948).

${ }^{7}$ Kh. L. Gildengershel, Zh. neorg. Khim., 3, 1326 (1958).

8 A. A. Grinberg and Yu. N. Kukushkin, Zh. neorg. Khim. 2, 106 (1957).

9 G. B. Bokii and G. A. Kukina, Kristallog. 2, 400 (1957).

10 I. I. Cherniaev, L. A. Nazarova and A. S. Mironova, Zh. neorg. Khim. 6, 2444 (1961).

11 L. N. Essen, Geometricheskiye isomery platiny i transvliyanie, Izd. 'Nauka': Moscow (1969).

12 L. N. Essen and T. N. Bukhtiyarova, Zh. neorg. Khim. 15, 1319 (1970).

13 A. W. Adamson, Disc. Faraday Soc. 29, 163(1960).

14 I. I. Cherniaev, G. S. Muraveiskaya and L. S. Korablina, Zh. neorg. Khim. 10, 733, 1045 (1965).

15 A. A. Grinberg and Yu. N. Kukushkin, Dokl. Ak. Nauk SŚSR, 145, 97 (1962).

16 Yu. N. Kukushkin, V. A. Rabinovich and R. A. Goloseeva, Zh. neorg. Khim. 14, 1863, 2820 (1969).

17 A. A. Grinberg and Y. N. Kukushkin, Dokl. Ak. Nauk SSSR, 140, 1076 (1961).

18 I. I. Cherniaev, E. V. Shenderetskaya and A. A. Koriagina, Zh. neorg. Khim. 5, 1163 (1960).

19 I. I. Cherniaev, L. A. Nazarova and A. S. Morozova, Theory and Structure of Complex Compounds, p 25. Warszawa (1964).

${ }^{20}$ M. A. Poray-Koshits and A. S. Antsyshkina, Dokl. Ak. Nauk SSSR, 146, 1102 (1962).

21 L. A. Nazarova, I. I.Cherniaev and A. S. Morozova, Zh. neorg. Khim. 10, 539 (1965).

22 I. I. Moiseev, M. N. Vargafik and Y. K. Syrkin, Dokl. Ak. Nauk. SSSR, 130, 820 (1960); 133, $377(1960)$.

${ }^{23}$ I. I. Moiseev, ' $\pi$-Komplexi $v$ zhidkofaznom okislenii olefinov', Izd. 'Nauka': Moscow (1970).

24 A. L. Davydov, Z. M. Vaisberg and L. E. Burkser, Zavod. Lab. 13, 1038 (1947).

25 A. K. Babko and Y. F. Shkaravskii, Zh. neorg. Khim. 6, 2091 (1961); 7, 1565 (1962).

26 Y. F. Shkaravskii, Ukr. Khim. Zh. 28, 1114 (1962); 30, 241 (1964).

27 Y. F. Shkaravskii, Zh. neorg. Khim. 10, 1179 (1965);11, 120 (1966).

28 E. A. Torchenkova, G. G. Stepanova and V. I. Spitsyn, Dokl. Ak. Nauk SSSR, 157, 1167 (1964).

29 E. A. Torchankova, Nguen Dyeu and V. I. Spitsyn, 'Tezisy dokladov X Vsesouznogo soveshchaniya po khimii kompleksnykh soedinenii', str. 129 (1969).

30 A. I. Kokorin, Zh. Obs. Khim. 24, 967 (1954); 27, 549 (1957). 


\section{COORDINATION CHEMISTRY IN THE USSR}

${ }^{31}$ Z. F. Shakhova et al., Zh. analit. Khim. 11, 698 (1956); 13, 211 (1958); 19, 734 (1964).

32 Z. F. Shakhova, G. N. Tishchenko and R. K. Motorkina, Zh. Obs. Khim. 26, 2663 (1956); 27, 1118(1957).

${ }^{33}$ P. Bajdala, E. A. Torchenkova and V. I. Spitsyn, Proceedings of the XIIIth ICCC, No. 387 (1970).

${ }^{34}$ V. I. Spitsyn, V. F. Chuvaev and V. Y. Kabanov, Dokl. Ak. Nauk SSSR, 152, 153 (1963).

35 V. F. Chuvaev, S. A. Bakhchisaraitseva and V. I. Spitsyn, Dokl. Ak. Nauk SSSR, 165, 1126 (1965).

36 V. F. Chuvaev and V. I. Spitsyn, Dokl. Ak. Nauk SSSR, 166, 160 (1966).

${ }^{37}$ V. F. Chuvaev. H. J. Lunk and V. I. Spitsyn, Dokl. Ak. Nauk SSSR, 181, 1156 (1968).

38 V. I. Spitsyn, Z. Anorg. Allg. Chem., 304, 196(1960).

39 V. I. Spitsyn and G. V. Kosmodemyanskaya, Omagiu Acad. Prof. Raluca Ripan, Edit. Acad. Republ. Soc. Romania, 584 (1966).

40 Z. M. Babeshkina, L. I. Martynenko and A. L. Grigoryev, Zh. neorg. Khim. 11, 1282 (1966).

41 N. A. Dobrynina, L. I. Martynenko, L. V. Ageeva and V. I. Spitsyn, Izvest. Ak. Nauk SSSR, Ser. Khim. 477 (1970).

42 A. S. Berliand, L. I. Martynenko, N. P. Potapova and V. I. Spitsyn, Dokl. Ak. Nauk SSSR, 189, $563(1969)$

43 A. I. Byrke, N. N. Magdesieva, L. I. Martynenko and V. I. Spitsyn, Zh. neor. Khim. 12, 666 (1967)

44 N. M. Prutkova and L. I. Martynenko, Zh. neorg. Khim. 14, 1531 (1969).

45 N. I. Sevostianova. L. I. Martynenko and V. I. Spitsyn. Zh. neorg. Khim. 15, 1234 (1970).

46 L. I. Martynenko and N. D. Mitrofanova, Vestnik MGU, N.1, 18 (1969).

47 L. I. Martynenko, G. A. Artiukhina and V. I. Spitsyn, Dokl. Ak. Nauk SSSR, 182, 600 (1968).

48 R. P. Kapitanova, G. L. Varlamova, N. I. Pechurova, L. I. Martynenko and V. I. Spitsyn, Zh. neorg. Khim. 16, 1286 (1971).

49 K. B. Yatsimirsky, N. A. Kostromina, Z. A. Sheka, N. K. Davidenko, F. E. Kriss and V. I. Ermolenko. Khimiya kompleksnykh soedinenii redkosemelnykh elementov. Izd. 'Naukova dumka': Kiev (1966).

50 N. D. Mitrofanova, L. I. Martynenko and A. I. Grigoryev, Zh. neorg. Khim. 9, 320 (1964).

51 L. I. Martynenko, V. I. Spitsyn and G. A. Artiukhina, Zh. neorg. Khim. 15, 931 (1970).

52 L. I. Martynenko, N. P. Potapova and V. I. Spitsyn, Izvest. Ak. Nauk SSSR, Ser. Khim. (1971) in press.

53 N. P. Potapova, Dissertation, M. Moscow Gos. University (1971).

54 N. A. Kostromina, Zh. neorg. Khim. 8, 1900 (1963); 11, 1116, 2340 (1966); 12, 511 (1967).

55 N. K. Davidenko and K. B. Yatsimirsky, Zh. neorg. Khim. 7, 700 (1966).

56 N. K. Davidenko and A. A. Zholdakov, Zh. neorg. Khim. 12, 1195, 3068 (1967); 14, 408 (1969).

57 K. B. Yatsimirsky, N. K. Davidenko, N. A. Kostromina and T. V. Ternovaya, Zh. Teor. Eksp. Khim. 1. 100 (1965).

58 K. B. Yatsimirsky and N. A. Kostromina, Zh. Teor. eksp. Khim. 2, 583 (1966).

${ }^{59}$ N. A. Kostromina, T. V. Termovaya, E. D. Romanenko and K. B. Yatsimirsky, Zi. Teor. eksp. Khim. 2, 673 (1966).

${ }^{60}$ E. D. Romanenko and N. A. Kostromina, Zh. neorg. Khim. 13, 1840 (1968).

${ }^{61}$ K. B. Yatsimirsky and N. K. Davidenko, Zh. strukt. Khim. 7, 532. 700 (1966).

${ }^{62}$ K. B. Yatsimirsky and N. K. Davidenko, Dokl. Ak. Nauk SSSR, 191, 384 (1970).

${ }^{63}$ N. A. Kostromina and B. A. Geller, Sb. Stroenie molekul i kvantovaya khimiya. 43. Izd. Naukova Dumka, Kiev (1970).

64 N. E. Brezhneva. V. I. Levin. M. G. Ratnikova and V. S. Novoselov. Radiokhim. 12. 259 (1970).

os L. N. Komissarova, G. Y. Pushkina, N. P. Khromeeva and V. I. Spitsyn, Z. Anorg. Allo. Chem. 344, 76(1966).

66 L. N. Komissarova, Yu. G. Eremin, V. S. Katochkina and T. M. Sas, Zh. neorg. Khim. (1971) in press.

67. L. N. Komissarova, V. G. Gulia and T. M. Sas, Izvest. Vyssh. Uchebnikh Zavedenii, Khim. khim. Tekh. 12,1315(1968).

68 B. N. Ivanov-Emin, A. M. Egorov, V. I. Romaniuk and E. N. Siforova, Zh. neorg. Khim. 15. 1224 (1970).

69 D. I. Mendeleev. Osnori Khim.. 8 izd.. 733 (1906). 


\section{I. SPITSYN}

70 The Transuranium Elements. Research Papers, edited by G. T. Seaborg, J. J. Katz and W. M. Manning, Parts I and II, McGraw-Hill: New York (1949).

${ }^{71}$ V. G. Khlopin, I zbrannye Trudi, Vol. II., Izd. Ak. Nauk SSSR: Moscow (1957).

72 B. A. Nikitin, Izbrannye Trudi, Izd. Ak. Nauk SSSR: Moscow (1956).

73 A. K. Molodkin and O. M. Ivanova, Zh. neorg. Khim. 10, 2456(1965).

74 A. K. Molodkin and E. G. Arutiunian, Zh. neorg. Khim. 10.352(1965).

75 A. K. Molodkin, G. A. Skotnikova and O. M. Ivanova, Zh. neorg. Khim. 10, 2243, 2441, 2675 (1965).

76 O. N. Evstafyeva, A. K. Molodkin et al. Zh. neorg. Khim. 11, 1306, 2241 (1966).

77 I. I. Cherniaev, Kompleksnye Soedineniya Urana. Sbornik Statei pod Redaktsiei. Izd. 'Nauka': Moscow (1964).

78 V. A. Golovnia and G. T. Bolotova, Zh. neorg. Khim. 6, 2284 (1961).

${ }^{79}$ V. M. Vdovenko, Khimiya Urana i Transuranovykh Elementov, Izd. Ak. Nauk SSSR (1960).

80 V. M. Vdovenko and D. N. Suglobov, Zh. fiz. Khim.34, 51(1960).

81 A. D. Gel'man, A. I. Mosk vin, L. I. Zaitsev and M. P. Mefodyeva, Kompleksnye Soedineniya Transuranovykh Elementov, Izd. Ak. Nauk SSSR: Moscow (1961).

82 V. F. Peretrukhin, N. N. Krot and A. D. Gel'man, Izv. Ak. Nauk SSSR, Ser. Khim. No. 10, $2663(1969)$.

83 V. F. Peretrukhin, N. N. Krot and A. D. Gel'man, Radiokhim. 12, 101 (1970).

${ }^{84}$ M. P. Mefodyeva, N. N. Krot and A. D. Gel'man, Radiokhim. 12, 232 (1970).

85 A. D. Gel'man, V. I. Blokhin, T. N. Bukhtiyarova and N. N. Krot, Zh. neorg. Khim. 15, 1899 (1970).

86 A. D. Gel'man and V. P. Zaitseva. Radiokhim. 7, 56(1965).

${ }^{87}$ A. I. Grigoryev, T. Yu. Orlova and A. V. Novoselova, Izv. Ak. Nauk SSSR. Neorg.Mater. 1, 1246(1965).

88 V. I. Spitsyn, I. D. Kolli, R. A. Rodionov and T. G. Sevastyanova, Dokl. Ak. Nauk SSSR, 160, $1101(1965)$.

89 V. I. Spitsyn, I. D. Kolli and E. M. Sadykova, 1zv. Ak. Nauk SSSR (in press) (1971).

90 E. N. Deichman et al. Zh. neorg. Khim.9, 803 (1964); 10,89(1965).

91 D. I. Riabchikov, I. N. Marov, V. K. Beliaeva and A. N. Ermakov, J. Inorg. Nucl. Chem. 26, 965 (1964).

92 I. N. Marov, A. N. Ermakov, V. K. Beliaeva and D. I. Riabchikov, Sbornik 'Sovremennye Metody Analiza', Izd. 'Nauka': Moscow (1965).

93 A. V. Ablov, L. N. Milkova and Y. V. Yablokov, Zh. neorg. Khim. 14, $686(1969)$.

94 E. V. Suntsov, A. V. Ablov et al. Dokl. Ak. Nauk SSSR, 179, 1352 (1968); 186, 613 (1969).

95 L. M. Romanov, A. V. Ablov and N. V. Gerbeleu, Zh. neorg. Khim. 14, 381 (1969).

96 A. V. Ablov, N. V. Gerbeleu and A. M. Romanov, Zh. neorg. Khim. 9, 2325 (1964); 13, 3024 (1968).

97 V. E. Pliushchev, S. B. Stepina and I. V. Vlasova, Dokl. Ak. Nauk SSSR, 180, 126 (1968).

98 S. B. Stepina, V. E. Pliushchev et al. Zh. neorg. Khim. 13, 545, 2570, 2838, 2865, $3116(1968)$.

99 V. E. Pliushchev, S. B. Stepina et al. Zh. neorg. Khim. 13, 2838 (1968); 14, 1700, 2857, 3100 (1969).

100 A. V. Nikolaev, A. A. Opalovsky et al. Dokl. Ak. Nauk SSSR, 189, 1025 (1969).

101 V. V. Korshak, S. V. Vinogradova et al. Vysokomol. Soedineniya, 2, 492, 498 (1960); 3, 1500 (1961); 6, 729, 2149 (1964).

102 V. V. Korshak, A. M. Poliakova et al., Izvest. Ak. Nauk SSSR, ser. khim. 440, 642 (1968).

103 V. A. Kargin, S. L. Davydova, N. A. Plate et al. Vysokomol. Soeditheniya, A-9, 134 (1967): A-10, 1004 (1968).

104 S. L. Davydova, N. A. Plate et al. Zh. fiz. Khim. 42.258, 990 (1968).

105 S. L. Davydova, N. A. Plate and V. A. Kargin, Proceedings of Tenth (1967) and Twelfth (1969) International Conference on Coordination Chemistry.

106 V. N. Tolmachev, L. A. Lomako and N. S. Pivnenko, Ukr. Khim., Zh. 32, 384 (1966).

107 N. M. Diatlova, V. Y. Temkina and I. D. Kolpakova, Kompleksony, Izd. Khimiya (1970).

108 N. M. Diatlova, T. Y. Medyntsev and M. I. Kabachnik, Zh. obshch. Khim. 38, 1076 (1968).

109 V. Y. Temkina, G. F. Yaroshenko and R. P. Lastovsky, Zh. anal. Khim. 897 (1970).

110 N. M. Diatlova, A. Ya. Fridman and R. P. Lastovsky, Zh. neorg. Khim. 15, 701 (1970).

111 A. N. Nesmeyanov, N. A. Volkenau and I. N. Bolesova, Dokl. Ak. Nauk SSSR, 149, 615 (1963); Tetrahedron Letters, 1725 (1968).

112 A. N. Nesmeyanov, N. A. Volkenau and L. S. Shilovtseva, Izvest. Ak. Nauk SSSR, ser. khim. $726(1969)$. 


\section{COORDINATION CHEMISTRY IN THE USSR}

113 A. N. Nesmeyanov, I. S. Astakhova, G. P. Zol'nikova, I. I. Kritskaya and Y. T. Strukov, Chem. Commun. 85 (1970).

114 A. N. Nesmeyanov, K. N. Anisimov, N. E. Korobova and A. A. Pasynsky, Dokl. Ak. Nauk SSSR, 181, $1142(1968) ; 182,112$ (1968).

115 A. N. Nesmeyanov, V. I. Gol'dansky et al. Izvest. Ak. Nauk SSSR, ser. khim. 793 (1968); Dokl. Ak. Nauk SSSR, 181, 921 (1968).

116 A. N. Nemeyanov, D. N. Kravtsov et al. Dokl. Ak. Nauk SSSR, 183, 1098 (1968); Izvest. Akad. Nauk SSSR, Ser. Khim., 1928 (1969).

117 O. A. Reutov, Pure appl. Chem. 17, 79 (1968).

118 E. N. Guryanova, Usp. Khim. 37, 1981 (1968).

119 K. A. Kocheshkov, E. N. Guryanova et al. Izv. Ak. Nauk SSSR, ser. khim. 728, 2201 (1967).

120 M. E. Volpin and V. B. Shur, Dokl. Ak. Nauk SSSR, 156, 1102 (1964).

121 M. E. Volpin, M. A. Ilatovskaya, L. V. Kosiakova and V. B. Shur, Chem. Commun. 1074 (1968).

122 M. E. Volpin, V. B. Shur, R. V. Kudriavtsev and L. A. Prodaiko, Chem. Commun. 1038 (1968).

123 Y. G. Borod'ko, A. E. Shilov, Usp. Khim. 38, 761 (1969).

124 N. T. Denisov, V. I. Shuvalov, N. I. Shuvalova, A. K. Shilova and A. E. Shilov, Kinet. Katal. 11, 813(1970).

125 K. B. Yatsimirsky, Zh. neorg. Khim. 1, 2306(1956);

K. B. Yatsimirsky and L. I. Budarin, Zh. neorg. Khim. 7, 1090 (1962).

126 K. B. Yatsimirsky, Kineticheskie Metody Analyza, Izd. Khimiya: Moscow (1967).

127 K. B. Yatsimirsky and E. E. Kriss, Dokl. Ak. Nauk SSSR, 168, 840 (1966); Zh. neorg. Khim. 13, 2370 (1968).

128 K. B. Yatsimirsky and L. I. Budarin, Usp. Khim. 37, 469 (1968); Dokl. Ak. Nauk SSSR, 170, 1117 (1966); 180, 1383(1968); Teor. eksp. Khim. 5, 507(1969).

129 B. P. Nikolsky, V. V. Pal'chevsky and R. G. Gorbunova, 'VIII Vsesouznoe Soveshch. po Khim. Kompleksn. Soed., Tezisy Dokladov' (1959); Zh. neorg. Khim. 6, 606 (1961).

130 M. S. Zakhar'yevsky and V. V. Pal'chevsky, Sb. Khimiya i Termodinamika Rastvorov, p 165. Izd. LGU (1964): (Leningrad); Vestn. LGU, 121 (No. 22) (1964); (Leningrad).

131 B. P. Nikolsky, A. A. Pendin and M. S. Kakhar'evsky, Zh. neorg. Khim. 12, 1803 (1967).

132 T. I. L'vova, A. A. Pendin, K. D. Shirko, B. P. Nikolsky, Vestn LGU;116, (16) (1967).

133 T. I. L'vova, A. A. Pendin and B. P. Nikolsky, Dokl. Ak. Nauk SSSR, 176, 586 (1967).

134 D. I. Riabchikov, I. N. Marov, Y. N. Dubrov, V. K. Beliaeva and A. N. Ermakov, Dokl. Ak. Nauk SSSR, 165, (1965).

135 I. N. Marov, Y. N. Dubrov, V. K. Beliaeva, A. N. Ermakov, D. I. Riabchikov, Zh. neorg. Khim. 11, 2443 (1966).

136 V. V. Zelentsov, et al. Dokl. Ak. Nauk SSSR, 155, 395 (1964); Zh. strukt. Khim. 6, 647 (1965); Dokl. Ak. Nauk SSSR, 177, 633 (1967); Zh. neorg. Khim. 15, 661 (1970).

137 V. V. Zelentsov, N. A. Subbotina et al. Zh. neorg. Khim. 15, 3283 (1970).

138 T. N. Polynova, N. G. Bokii and M. A. Poray-Koshits, Zh. strukt. Khim. 6, 878 (1965).

139 Y. M. Nesterova, M. A. Poray-Koshits, A. V. Upadysheva and L. A. Kozitsina, Zh. Strukt. Khim. 7, 129 (1966).

140 T. N. Polynova, N. P. Bel'skaya, D. Tiurk de Garsia Banus, M. A. Poray-Koshits and L. I. Martynenko, Zh. strukt. Khim. 11, 164 (1970).

141 N. V. Novozhilova, T. N. Polynova, M. A. Poray-Koshits, L. I. Martynenko, Zh. Strukt. Khim. 8, 553 (1967).

142 E. M. Shustorovich and M. E. Diatkina, Zh. strukt. Khim. 1, 109 (1960); 2, 49 (1961); 3, 345 (1962).

143 O. Y. Lopatko, N. M. Klimenko and M. E. Diatkina, Dokl. Ak. Nauk, SSSR, 192, 1083 (1970).

144 A. A. Grinberg, Vvedenie v Khimiu Kompleksnykh Soedinenii, 2nd ed., GNTI, Moscow (1951).

145 A. A. Grinberg, Vvedenie v Khimiyu Kompleksnykh Soedinenii, 3rd ed., Izd. Khimiya: Moscow (1966).

146 A. A. Grinberg and K. B. Yatsimirsky, Izvest. Ak. Nauk SSSR, OKHN, 239 (1952).

147 K. B. Yatsimirsky, Zh. neorg. Khim. 14, 2603 (1969).

${ }^{148}$ K. B. Yatsimirsky, Kompleksoobrazovanie i Periodicheskaya Sistema Elementov, Sbornik '100 Let Periodicheskogo Zakona Khimicheskikh Elementov', Izd. 'Nauka': Moscow (1969). 